\title{
Morphological profile determines the frequency of spontaneous calcium events in astrocytic processes
}

Yu-Wei Wu ${ }^{1,2,6,7}$, Susan Gordleeva ${ }^{3,6}$, Xiaofang Tang ${ }^{1,6}$, Pei-Yu Shih ${ }^{1}$, Yulia

Dembitskaya ${ }^{1,3}$, Alexey Semyanov ${ }^{1,3,4,5,7}$

Author affiliations:

${ }^{1}$ Brain Science Institute (BSI), RIKEN, Wako-shi, Saitama, Japan

${ }^{2}$ Institute of Molecular Biology, Academia Sinica, 128 Academia Road, Section 2, Nankang, Taipei 11529, Taiwan

${ }^{3}$ University of Nizhny Novgorod, Nizhny Novgorod, Russia

${ }^{4}$ Shemyakin-Ovchinnikov Institute of Bioorganic Chemistry, Russian Academy of Sciences, Moscow, Russia

${ }^{5}$ All-Russian Research Institute of Medicinal and Aromatic Plants, Grina street 7, Moscow, 113628, Russia

${ }^{6}$ Contributed equally

${ }^{7}$ Corresponding authors

Running title: Morphology-dependent calcium activity in astrocytes

\section{Main points:}

- Majority of spontaneous $\mathrm{Ca}^{2+}$ events start in thin astrocytic processes

- Higher surface-to-volume ratio of the process is responsible for larger intracellular $\mathrm{Ca}^{2+}$ fluctuations

- Larger intracellular $\mathrm{Ca}^{2+}$ fluctuations trigger $\mathrm{Ca}^{2+}$-dependent $\mathrm{Ca}^{2+}$ release

\section{Acknowledgments}

The authors thank Dr. Hiroko Bannai for help with primary hippocampal astrocyte/neuron co-culture and transfection. The research was supported by the Russian Science Foundation (project No. 16-14-00201).

\section{Word Count}

Total: 10725 (incl. references and figure legends)

Abstract: 244

Introduction: 472

Materials and Methods: 1992

Results: 2508

Discussion: 1128

Figures: 9

Tables: 1 


\section{Abstract}

Astrocytes express a complex repertoire of intracellular $\mathrm{Ca}^{2+}$ transients (events) that represent a major form of signaling within individual cells and in the astrocytic syncytium. These events have different spatiotemporal profiles, which are modulated by neuronal activity. Spontaneous $\mathrm{Ca}^{2+}$ events appear more frequently in distal astrocytic processes and independently from each other. However, little is known about the mechanisms underlying such subcellular distribution of the $\mathrm{Ca}^{2+}$ events. Here we identify the initiation points of the $\mathrm{Ca}^{2+}$ events within the territory of single astrocytes expressing genetically encoded $\mathrm{Ca}^{2+}$ indicator GCaMP2 in culture or in hippocampal slices. We found that most of the $\mathrm{Ca}^{2+}$ events start in thin distal processes. Our mathematical model demonstrated that a high surface-to-volume (SVR) of the thin processes leads to increased amplitude of baseline $\mathrm{Ca}^{2+}$ fluctuations caused by a stochastic opening of $\mathrm{Ca}^{2+}$ channels in the plasma membrane. Suprathreshold fluctuations trigger $\mathrm{Ca}^{2+}$-induced $\mathrm{Ca}^{2+}$ release $(\mathrm{CICR})$ from the $\mathrm{Ca}^{2+}$ stores by activating inositol 1,4,5-trisphosphate $\left(\mathrm{IP}_{3}\right)$ receptors. In agreement with the model prediction, the spontaneous $\mathrm{Ca}^{2+}$ events frequency depended on the extracellular $\mathrm{Ca}^{2+}$ concentration. Astrocytic depolarization by high extracellular $\mathrm{K}^{+}$increased the frequency of the $\mathrm{Ca}^{2+}$ events through activation of voltage-gated $\mathrm{Ca}^{2+}$ channels (VGCC) in cultured astrocytes. Our results suggest that the morphological profile of the astrocytic processes is responsible for tuning of the $\mathrm{Ca}^{2+}$ event frequency. Therefore, the structural plasticity of astrocytic processes can be directly translated into changes in astrocytic $\mathrm{Ca}^{2+}$ signaling. This may be important for both physiological and pathological astrocyte remodeling.

\section{Keywords}

Astrocyte, process, microdomain, calcium imaging, calcium channel, GCaMP, $\mathrm{IP}_{3}$ receptors 


\section{Introduction}

$\mathrm{Ca}^{2+}$ activity is a major form of signaling in astrocytes (Agulhon et al., 2008; Bazargani \& Attwell, 2016; Rusakov, Zheng, \& Henneberger, 2011; Verkhratsky, Orkand, \& Kettenmann, 1998). Changes in intracellular $\mathrm{Ca}^{2+}\left(\left[\mathrm{Ca}^{2+}\right]_{\mathrm{i}}\right)$ are required for many astrocytic functions, including release of gliotransmitters (Araque et al., 2014; Zorec et al., 2012), regulation of local blood flow (Petzold \& Murthy, 2011), regulation of $\mathrm{K}^{+}$ uptake (F. Wang et al., 2012), morphological plasticity of astrocytic processes (Heller \& Rusakov, 2015; Tanaka et al., 2013). Large and slow astrocytic $\mathrm{Ca}^{2+}$ events are thought to be predominantly mediated by the metabotropic pathways linked to inositol $1,4,5$ trisphosphate $\left(\mathrm{IP}_{3}\right)$ production, which triggers $\mathrm{CICR}$ through $\mathrm{IP}_{3}$ receptors $\left(\mathrm{IP}_{3} \mathrm{Rs}\right)(\mathrm{De}$ Young \& Keizer, 1992; Kirischuk, Kirchhoff, Matyash, Kettenmann, \& Verkhratsky, 1999; Ullah, Jung, \& Cornell-Bell, 2006). Stimulation of Shaffer collaterals or an application of metabotropic glutamate receptor (mGluR) agonists increase the frequency and the spreading of the astrocytic $\mathrm{Ca}^{2+}$ events in hippocampal slices (Haustein et al., 2014; Sun et al., 2014; Wu et al., 2014). The blockers of mGluRs or tetrodotoxin (TTX, blocks neuronal action potentials) reduce the frequency and the spread of the spontaneous $\mathrm{Ca}^{2+}$ events in astrocytes (Haustein et al., 2014; Rungta et al., 2016; Sun et al., 2014; $\mathrm{Wu}$ et al., 2014). However, they fail to block astrocytic $\mathrm{Ca}^{2+}$ activity completely (Haustein et al., 2014; Rungta et al., 2016; Sun et al., 2014; Wu et al., 2014). Indeed, $\mathrm{Ca}^{2+}$ can enter astrocytes through ionotropic receptors in plasma membrane (Fumagalli et al., 2003; Palygin, Lalo, Verkhratsky, \& Pankratov, 2010; C. M. Wang, Chang, Kuo, \& Sun, 2002). Yet, the spontaneous $\mathrm{Ca}^{2+}$ events are still detectable in astrocytes in the presence of AMPA, NMDA, GABA ${ }_{B}, P_{2} X$, and $P_{2} Y$ receptor blockers (Rungta et al., 2016; Wu et al., 2014). Thus, at least a fraction of the spontaneous $\mathrm{Ca}^{2+}$ events in astrocytes is not triggered by activation of these receptors.

In fact, astrocytes possess several other mechanisms for the $\mathrm{Ca}^{2+}$ entry through the plasma membrane. Expression of VGCCs has been reported in astrocytes both in culture (Latour, Hamid, Beedle, Zamponi, \& Macvicar, 2003; Parpura, Grubisic, \& Verkhratsky, 2011; Yaguchi \& Nishizaki, 2010) and in hippocampal slices (Letellier et al., 2016). Activation of L-type VGCCs upon astrocyte depolarization is involved in the release of gliotransmitters and regulation of presynaptic strengths (Letellier et al., 2016; Yaguchi \& Nishizaki, 2010). However, the $\mathrm{Ca}^{2+}$ entry through the VGCCs may still need 
to be amplified by CICR (Carmignoto, Pasti, \& Pozzan, 1998). $\mathrm{Na}^{+} / \mathrm{Ca}^{2+}$ exchanger (NCX) can transport $\mathrm{Ca}^{2+}$ into the astrocytes upon increase in intracellular $\mathrm{Na}^{+}$ concentration which occurs during glutamate uptake (Brazhe, Verisokin, Verveyko, \& Postnov, 2018; Oschmann, Mergenthaler, Jungnickel, \& Obermayer, 2017; Rojas et al., 2007). Other sources of the $\mathrm{Ca}^{2+}$ entry in astrocytes include store-operated channels (SOCs) ORAI1 and transient receptor potential type A channels (TRPAs) (Bazargani \& Attwell, 2016; Shigetomi, Jackson-Weaver, Huckstepp, O'Dell, \& Khakh, 2013).

Notably, the majority of $\mathrm{Ca}^{2+}$ events start in fine distal astrocytic processes (Asada et al., 2015; Bindocci et al., 2017; Nakayama, Sasaki, Tanaka, \& Ikegaya, 2016; Nett, Oloff, \& McCarthy, 2002). This can be attributed to the location of synapses (Di Castro et al., 2011) and subcellular distribution of receptors, channels and transporters in astrocytes (Arizono et al., 2012; Hayashi \& Yasui, 2015). Here we show that spontaneous $\mathrm{Ca}^{2+}$ events can start in thin astrocytic processes because of their high SVR: $\mathrm{Ca}^{2+}$ entry though plasma membrane produces larger elevations in $\left[\mathrm{Ca}^{2+}\right]_{\text {। }}$ that more likely to trigger CICR.

\section{Materials and Methods}

\subsection{Primary Hippocampal Astrocyte/Neuron Co-culture and Transfection}

Primary hippocampal astrocyte/neuron co-cultures were prepared from Wistar rats (Japan SLC Inc.) at embryonic day 18-20 with slight modifications of the previously described procedure (Wu et al., 2014). All procedures were performed in accordance with RIKEN regulations. Briefly, hippocampi from 6 to 8 pups were dissociated in petri dishes filled with Hank's balanced salt solution (HBSS) containing $20 \mathrm{mM} \mathrm{N}-2-$ hydroxyethyl-piperazine-N'-2-ethane-sulfonic acid (HEPES). The dissected hippocampi were digested by incubation in $3 \mathrm{ml} \mathrm{HBSS}$ containing $20 \mathrm{mM}$ HEPES, $0.125 \%$ trypsin, and $0.025 \%$ DNase I for $5 \mathrm{~min}$ at $37^{\circ} \mathrm{C}$. After incubation, the pieces were washed 3 times with HBSS containing $20 \mathrm{mM}$ HEPES and triturated with pipettes in the plating medium containing Minimal Essential Medium, B27, glutamine, sodium pyruvate, and penicillin-streptomycin. The cells were plated at a density of $1.2-1.4 \times 10^{5}$ cells/well in culture plates containing $18-\mathrm{mm}$ glass coverslips coated with $0.04 \%$ polyethyleneimine (Sigma-Aldrich, St. Louis, MO). Primary cell cultures were maintained at $37^{\circ} \mathrm{C}$ in a $5 \%$ $\mathrm{CO}_{2}$ humid incubator until used for experiments at 7 to 13 days in vitro. Every $3 \mathrm{~d}$ day, 
half of the volume of the medium was replaced with Neurobasal medium containing B27, glutamine, and penicillin-streptomycin. These procedures lead astrocytes to develop the complex shapes without a need for serum-free base medium as previously suggested (Liddelow et al., 2017). For transfection, a coverslip in $1 \mathrm{ml}$ culture medium was supplied with the transfection mixture containing $100 \mu$ OPTI-MEM (Invitrogen), $0.5 \mu \mathrm{g}$ GCaMP2 DNA plasmid, and $1 \mu \mathrm{l}$ Lipofectamine 2000 Transfection Reagent (Invitrogen). The culture was incubated with this mixture for 24 hours before imaging.

\section{$2.2 \mathrm{Ca}^{2+}$ Imaging in Cultured Astrocytes}

$\mathrm{Ca}^{2+}$ imaging of GCaMP2-expressing cultured astrocytes was performed in a recording chamber where the cultures were continuously superfused with a balanced salt solution containing (in mM): $115 \mathrm{NaCl}, 5.4 \mathrm{KCl}, 2 \mathrm{CaCl}_{2}, 1 \mathrm{MgCl}_{2}, 10 \mathrm{D}$-glucose, and $20 \mathrm{HEPES}$ $\left(\mathrm{pH} 7.4,33-34^{\circ} \mathrm{C}\right)$. Fluorescence was detected using an inverted microscope (IX70, Olympus) equipped with an objective lens Plan Apo 60x, NA 1.42 (Olympus) and a cooled charge-coupled device camera (array size: 256 × 337 pixels, $0.174 \mu \mathrm{m}^{2} /$ pixel; ORCA II-ER, Hamamatsu Photonics). A light source, a 490-nm light-emitting diode illumination system (precisExcite, CoolLED), and appropriate filter sets (470-490 nm for excitation; 515-550 nm for emission) were used. Images were acquired at $2 \mathrm{~Hz}$ using MetaView software (Meta Imaging, Dowington, PA). Spontaneous $\mathrm{Ca}^{2+}$ activity was recorded for $20 \mathrm{~min}$ in the presence of a cocktail of blockers for voltage-gated $\mathrm{Na}^{+}$

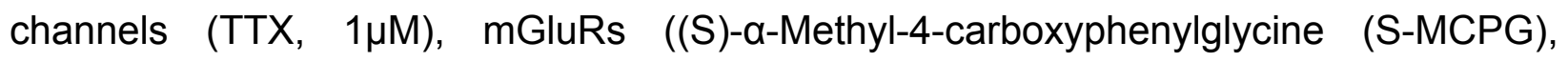
$100 \mu \mathrm{M})$, NMDA receptors (D-2-amino-5-phosphonovalerate (D-AP5), $25 \mu \mathrm{M}$ ), AMPA receptors (2,3-Dioxo-6-nitro-1,2,3,4-tetrahydrobenzo[f]quinoxaline-7-sulfonamide $(\mathrm{NBQX}), 25 \mu \mathrm{M}), \quad \mathrm{GABA}_{B}$ receptors (3-[[(3,4-Dichlorophenyl)methyl]amino]propyl] diethoxymethyl)phosphinic acid (CGP 52432), $5 \mu \mathrm{M}$ ), and purinergic P2 receptors (Pyridoxalphosphate-6-azophenyl-2',4'-disulfonic acid (PPADS), $30 \mu \mathrm{M}$ ). In experiments with different extracellular $\mathrm{Ca}^{2+}$ concentrations $(2,3$, and $4 \mathrm{mM})$ imaging was performed during $10 \mathrm{~min}$ for each concentration.

\subsection{Estimation of Surface-to-Volume Ratio}

Morphology of the cultured astrocytes was reconstructed from baseline fluorescence images of GCaMP2. Imaging was done with a laser scanning microscope FV-1000 
(Olympus, Japan) equipped with a $488 \mathrm{~nm}$ laser and a 60x water immersion objective (NA 1.0). The heights of the astrocytic processes were estimated by the full-width-athalf-maximum (half-width) of the fluorescence signal along the z-axis (Figure 3A and inset). The conversion factor between the heights of the processes imaged with the confocal microscopy and fluorescence intensity of the same processes imaged with CCD camera was obtained from linear regression ( $n=23$ processes/3 cells; Figure 3D). The SVRs of the processes were then calculated as a triangle from the half-width (HW) and the height of the process as

$S V R=\frac{\text { Perimeter }}{\text { Area }}=\frac{2 * H W+2 * \sqrt{H W^{2}+H e i g h t^{2}}}{H W * H e i g h t}$

\subsection{Mitochondria staining}

The cultured astrocytes were treated with $50 \mathrm{nM}$ MitoTracker Red CMXRos (Thermo Fisher Scientific Inc., USA) for $15 \mathrm{~min}$ at $37^{\circ} \mathrm{C}$ and then washed twice by culture medium and one time by Neurobasal medium (Thermo Fisher Scientific Inc., USA). The cultured cells were then fixed with $3.7 \%$ formaldehyde at room temperature for $10 \mathrm{~min}$, followed by washing with PBS before mounting and imaging.

\subsection{Two-photon $\mathrm{Ca}^{2+}$ imaging in hippocampal slices}

The transverse hippocampal slices were prepared from 5-6 months-old double transgenic mice carrying tetO-GCaMP2 and GLT-1-tTA, which led to astrocyte-specific expression of GCaMP2 (Tanaka et al., 2013). The animals were kept and killed according to RIKEN regulations. The brains were removed, and the two hippocampi were dissected. The 350- $\mu \mathrm{m}$ thick slices were prepared with vibrating microtome Microm HM 650 V (Thermo Fisher Scientific Inc., USA) in an ice-cold cutting solution containing (in mM): 75 sucrose, $87 \mathrm{NaCl}, 2.5 \mathrm{KCl}, 0.5 \mathrm{CaCl}_{2}, 1.25 \mathrm{NaH}_{2} \mathrm{PO}_{4}, 7 \mathrm{MgCl}_{2}$, $25 \mathrm{NaHCO}_{3}, 1 \mathrm{Na}$-ascorbate, and $11 \mathrm{D}$-glucose. Then the slices were transferred to an interfaced chamber with a storage solution containing (in $\mathrm{mM}$ ): $127 \mathrm{NaCl}, 2.5 \mathrm{KCl}, 1.25$ $\mathrm{NaH}_{2} \mathrm{PO}_{4}, 1 \mathrm{MgCl}_{2}, 1 \mathrm{CaCl}_{2}, 25 \mathrm{NaHCO}_{3}$, and $25 \mathrm{D}$-glucose, and kept at room temperature for at least $1 \mathrm{~h}$ prior imaging. Then the slices were transferred to an imaging chamber and superfused with a Ringer solution containing (in $\mathrm{mM}$ ): $127 \mathrm{NaCl}$, $2.5 \mathrm{KCl}, 1.25 \mathrm{NaH}_{2} \mathrm{PO}_{4}, 1 \mathrm{MgCl}_{2}, 2 \mathrm{CaCl}_{2}, 25 \mathrm{NaHCO}_{3}$, and 25 D-glucose at $34^{\circ} \mathrm{C}$. All solutions were saturated with $95 \% \mathrm{O}_{2}$ and $5 \% \quad \mathrm{CO}_{2}$ gas mixture. The osmolarity was 
adjusted to 300 mOsm. The astrocyte-specific expression of GCaMP2 was sparse, therefore, individual astrocytes could be imaged. Two-photon time-lapse imaging (1 frame per second) was done with the laser scanning microscope FV-1000 (Olympus, Japan). GCaMP2 was excited at $890 \mathrm{~nm}$ wavelength with a femtosecond laser Chameleon XR (Coherent, USA) and the fluorescence was collected with a 60x water immersion objective (NA 1.0) and a 495-540 $\mathrm{nm}$ bandpass filter.

\subsection{Drugs and Chemicals}

All drugs were made from $1000 x$ stock solutions that were kept frozen at $-20^{\circ} \mathrm{C}$ in 100 $200 \mu$ l aliquots. CGP 52432, TTX, S-MCPG, PPADS, NBQX, HC 030031, and D-AP5 were purchased from Tocris Cookson (Bristol, UK). The astrocytic marker, Sulforhodamin 101, was purchased from Thermo Fisher Scientific Inc. (USA), and all other drugs and chemicals were purchased from Sigma-Aldrich (USA).

\subsection{Data Analysis and Statistics}

Whole $\mathrm{Ca}^{2+}$ events were automatically identified with custom-made software (Matlab, Mathworks) and analyzed following the algorithm described by Wu et al., 2014. In brief, the events were defined by combining two different thresholds: a dynamic threshold and an absolute threshold. The dynamic threshold was set at two standard deviations of baseline fluorescence fluctuations in each pixel. The absolute threshold was $\Delta F / F=0.1$. If the neighboring 'active' pixels passed the absolute threshold and contained areas detected by the dynamic threshold, the areas were defined as the $\mathrm{Ca}^{2+}$ event area in a particular frame. The event areas were then connected in the subsequent frames forming thus whole $\mathrm{Ca}^{2+}$ event reconstructed in $\mathrm{x}$-y-time $3 \mathrm{D}$ space (Figure $2 \mathrm{C}$ ). Two Matlab (version 2015a) functions were used to find the weighted centroid of the first frame of each whole $\mathrm{Ca}^{2+}$ event, defined as the initiation point: "bwconncomp" and "regionprops". The function "regionprops" returned the coordinates specifying the center of the region based on location and intensity value (Figure 2D).

Statistical significance was tested using Wilcoxon signed-rank test for paired comparison; Friedman test for equivalent repeated measurement (RM) one-way analysis of variance (ANOVA); two-way RM ANOVA followed by post-hoc Bonferroni's multiple comparisons for the paired measurements across treatments and 
morphological parameters using Prism 7.0 (GraphPad, USA). The level of significance was set at $p<0.05$. All group measures presented in the figures and in the text are given as mean \pm the standard error of mean (SEM).

\subsection{Modeling of $\mathrm{Ca}^{2+}$ Dynamics}

Astrocytic $\left[\mathrm{Ca}^{2+}\right]_{i}$ changed due to several types of effluxes and influxes considered in the model. $\mathrm{Ca}^{2+}$ was released to the cytosol from endoplasmic reticulum (ER) through $\mathrm{IP}_{3} \mathrm{Rs}\left(J_{I P 3}\right)$. Sarco/endoplasmic reticulum $\mathrm{Ca}^{2+}$-ATPase (SERCA) pumped $\mathrm{Ca}^{2+}$ back into the ER $\left(J_{\text {pump }}\right)$. In addition, we introduced a leak current from the ER to the cytosol $\left(J_{\text {leak }}\right)$. The influx and the efflux of $\mathrm{Ca}^{2+}$ through the plasma membrane were also considered ( $J_{\text {in }}$ and $J_{\text {out }}$, respectively)

The balance of the $\mathrm{Ca}^{2+}$ fluxes to and from the cytosol was described by:

$\frac{d\left[\mathrm{Ca}^{2+}\right]_{i}}{d t}=J_{I P 3}-J_{\text {pump }}+J_{\text {leak }}+J_{\text {in }}-J_{\text {out }}$.

The kinetics of the $I P_{3} R$ mediated flux was based on the Li-Rinzel simplification (Y. X. Li \& Rinzel, 1994) of the De Young-Keizer model (De Young \& Keizer, 1992):

$J_{I P 3}=c_{1} v_{1} m_{\infty}^{3} h^{3}\left(\left[\mathrm{Ca}^{2+}\right]_{E R}-\left[\mathrm{Ca}^{2+}\right]_{i}\right)$.

These kinetics were written analogously to the Hodgkin-Huxley model of the action potential (Hodgkin \& Huxley, 1952). $c_{1}$ is the ratio of the ER vs the cytosol volumes (Ullah et al., 2006). $v_{1}$ is the maximal rate of the $\mathrm{IP}_{3}$-dependent CICR. The driving force for the $\mathrm{Ca}^{2+}$ fluxes was created by the concentration gradient between the $\mathrm{ER}\left(\left[\mathrm{Ca}^{2+}\right]_{E R}\right)$ and the cytosol $\left(\left[\mathrm{Ca}^{2+}\right]_{i}\right)$.

$\left[\mathrm{Ca}^{2+}\right]_{E R}=\frac{\left[\mathrm{Ca}^{2+}\right]_{c e l l}-\left[\mathrm{Ca}^{2+}\right]_{i}}{c_{1}}$

where $\left[\mathrm{Ca}^{2+}\right]_{\text {cell }}$ is the total cellular $\mathrm{Ca}^{2+}$ concentration.

The activation variable of the $\mathrm{IP}_{3} \mathrm{R} m_{\infty}$ was described by

$m_{\infty}=\left(\frac{\left[I P_{3}\right]}{\left[I P_{3}\right]+d_{1}}\right)\left(\frac{\left[C a^{2+}\right]_{i}}{\left[C a^{2+}\right]_{i}+d_{5}}\right)$,

where $\left[\mathrm{IP}_{3}\right]$ is the $\mathrm{IP}_{3}$ concentration in the cytosol, $d_{1}$ is the dissociation constant for $\mathrm{IP}_{3}$, $d_{5}$ is the $\mathrm{Ca}^{2+}$ activation constant (see Table 1 ). 
The inactivation variable of the $\mathrm{IP}_{3} \mathrm{R} h$ was modeled as a dynamic variable (Y. X. Li \& Rinzel, 1994):

$\frac{d h}{d t}=\frac{h_{\infty}-h}{\tau_{h}}$

$\tau_{h}=\frac{1}{a_{2}\left(Q_{2}+\left[C a^{2+}\right]_{i}\right)}$,

$h_{\infty}=\frac{Q_{2}}{Q_{2}+\left[C a^{2+}\right] i}$,

$Q_{2}=d_{2}\left(\frac{\left[I P_{3}\right]+d_{1}}{\left[I P_{3}\right]+d_{3}}\right)$

where $d_{1}$ is the dissociation constant for $\mathrm{IP}_{3}, d_{3}$ is the receptor dissociation constant for $\mathrm{IP}_{3}$ (see Table 1).

The SERCA mediated flux from the cytosol to the ER was described by the Hill-type kinetic model (Y. X. Li \& Rinzel, 1994):

$J_{\text {pump }}=\frac{v_{3}\left[\mathrm{Ca}^{2+}\right]_{i}^{2}}{\left[\mathrm{Ca}^{2+}\right]_{i}^{2}+k_{3}^{2}}$

where $v_{3}$ is maximal $\mathrm{Ca}^{2+}$ uptake and $k_{3}$ is activation constant for $\mathrm{ATP}_{-} \mathrm{Ca}^{2+}$ pump.

The leak flux from the ER to the cytosol was described by:

$J_{\text {leak }}=c_{1} v_{2}\left(\left[\mathrm{Ca}^{2+}\right]_{E R}-\left[\mathrm{Ca}^{2+}\right]_{i}\right)$,

where $V_{2}$ is the maximal leak flux through $\mathrm{Ca}^{2+}$ channels.

The $\mathrm{Ca}^{2+}$ influx through plasma membrane $\left(J_{i n}\right)$ was described by the sum of 3 fluxes: the constant $\mathrm{Ca}^{2+}$ influx $\left(J_{\text {pass }}\right)$ through passive channels, the capacitive $\mathrm{Ca}^{2+}$ entry $\left(J_{C C E}\right)$, and the influx through VGCCs $\left(J_{V G C C}\right)$.

$J_{\text {in }}=J_{\text {pass }}+J_{C C E}+J_{V G C C}$

$J_{C C E}$ depended on the $\mathrm{IP}_{3}$ concentration (Dupont \& Goldbeter, 1993):

$J_{C C E}=v_{6} \frac{\left[I P_{3}\right]^{2}}{\left[I P_{3}\right]^{2}+k_{2}^{2}}$

$J_{V G C C}$ was calculated as described in (Zeng, Li, Zeng, \& Chen, 2009): 
$J_{V G C C}=-\frac{I_{V G C C}}{z_{C a} F V}$

where $\mathrm{z}_{\mathrm{Ca}}$ is the valence of $\mathrm{Ca}^{2+} ; F$ is the Faraday constant; $V$ is the volume of an astrocytic compartment. Since we considered a chunk of an astrocytic process as a cylinder with radius $r$ and unitary length $I=1$, the volume of the process was: $V=\pi r^{2} I=$ $\pi r^{2}$.

$I_{V G C C}=g_{V G C C} m_{V G C C} h_{V G C C}\left(V_{m}-E_{C a}\right)$

where $g_{V G C C}$ is VGCC-mediated conductance. $g_{V G C C}=g S$, where $g$ is the conductance density and $S$ is the surface of the plasma membrane, which was equal to the side surface of the cylinder with unitary length $I=1: S=2 \pi r l=2 \pi r ; m_{\mathrm{VGCC}}$ and $h_{\mathrm{VGCC}}$ are gates that regulate activation and inactivation of the VGCCs (Zeng et al., 2009):

$h_{V G C C}=\frac{0.00045}{0.00045+\left[\mathrm{Ca}^{2+}\right]_{i}}$.

The value of $m_{V G C C}$ exponentially relaxed to the steady-state value of $m_{V G C C \infty}$ :

$$
\begin{aligned}
& d m_{V G C C}=\frac{m_{V G C C \infty}-m_{V G C C}}{\tau_{m}} d t+\sigma_{m} d \omega_{m}, \\
& m_{V G C C \infty}=\frac{1}{1+\exp \left(-\left(V_{m}+50\right) / 3\right)}, \\
& \tau_{m}=18 \exp \left(-\left(\left(V_{m}+45\right) / 20\right)^{2}\right)+1.5 .
\end{aligned}
$$

To account for stochastic openings of VGCCs, we added a Wiener process $\sigma_{m} d \omega_{m}$. The variance of the zero-mean Gaussian white noise $\sigma_{m}{ }^{2}$ was defined as in (Riera, Hatanaka, Uchida, Ozaki, \& Kawashima, 2011):

$\sigma_{m}^{2}=\frac{m_{\mathrm{VGCC} \infty}-m_{\mathrm{VGCC}}}{\tau_{m} N}$

where $N$ is the number of VGCCs.

Astrocytic membrane potential $\left(V_{m}\right)$ is mostly determined by $\mathrm{K}^{+}$conductance. Therefore, in this study, the $\mathrm{K}^{+}$Nernst potential was used to approximate $V_{m}$ by adding a modulation factor $\varepsilon$, which was chosen from the previous experiments (Schipke et al., 2008): 
$V_{m}=\frac{R T}{z_{K} F} \ln \frac{\left[K^{+}\right]_{o}}{\left[K^{+}\right]_{i}}+\varepsilon$

where $R$ is the ideal gas constant, $T$ is the absolute temperature, $\mathrm{z}_{\mathrm{K}}$ is the valence of $\mathrm{K}^{+}$ and $F$ is the Faraday constant. $\left[\mathrm{K}^{+}\right]_{\mathrm{o}}$ and $\left[\mathrm{K}^{+}\right]_{\mathrm{i}}$ are the extracellular and intracellular $\mathrm{K}^{+}$ concentrations, respectively.

$E_{C a}$ is the Nernst potential for $\mathrm{Ca}^{2+}$ :

$E_{C a}=\frac{R T}{z_{C a} F} \ln \frac{\left[\mathrm{Ca}^{2+}\right]_{o e}}{\left[\mathrm{Ca}^{2+}\right]_{i}}$,

where $\left[\mathrm{Ca}^{2+}\right]_{\mathrm{oe}}$ is the effective extracellular $\mathrm{Ca}^{2+}$ concentration. The compliance with experimental data was achieved in case of $\left[\mathrm{Ca}^{2+}\right]_{\mathrm{oe}}=\left(2.00181+0.21691 \ln \left(\left[\mathrm{Ca}^{2+}\right]_{0^{-}}\right.\right.$ 0.0099)).

The leak efflux from the cytosol to the extracellular space was calculated following (Ullah et al., 2006):

$J_{\text {out }}=k_{1}\left[\mathrm{Ca}^{2+}\right]_{i}$

$\left[\mathrm{IP}_{3}\right]$ was determined by the $\mathrm{IP}_{3}$ production by phospholipase $\mathrm{C}(\mathrm{PLC}) \delta\left(J_{\delta}\right)$ and by the $\mathrm{IP}_{3}$ degradation as described in (Ullah et al., 2006):

$\frac{d\left[I P_{3}\right]}{d t}=J_{\delta}-\frac{1}{\tau_{r}}\left(\left[I P_{3}\right]-\left[I P_{3}^{*}\right]\right)$,

where $\left[\mathrm{IP}_{3}{ }^{*}\right]$ is steady state concentration of $\mathrm{IP}_{3}$ and $J_{\delta}$ was modeled as described in (De Young \& Keizer, 1992; Ullah et al., 2006):

$J_{\delta}=v_{4}\left(\frac{\left[C a^{2+}\right]_{i}+(1-\alpha) k_{4}}{\left[C a^{2+}\right]_{i}+k_{4}}\right)$.

A sketch of the fluxes is shown in Figure 4A. The descriptions and the values of used parameters are given in the Table 1.

\section{Results}

\subsection{Spontaneous $\mathrm{Ca}^{2+}$ events initiation points depend on the width of the process}

$\mathrm{Ca}^{2+}$ activity was monitored in individual astrocytes transfected with the genetically encoded $\mathrm{Ca}^{2+}$ sensor GCaMP2. To avoid interference from neighboring astrocytes, imaging was performed in low-density astrocytic cultures. The morphological profile of 
individual astrocytes was determined from the baseline fluorescence of GCaMP2 (Figure 1A). The size of the process was defined by the width of the cross-section at half of the maximum fluorescence (half-width; HW) (Figure 1B). 18 cross-sections with $10^{\circ}$ increment were plotted at every pixel within the astrocytic territory (Figure 1C). The minimum HW among the 18 cross-sections was then assigned to the pixel (Figure 1D). The astrocyte territory was colored according to the local HWs (Figure 1E,G). The probability density of local HWs $(\operatorname{Pr}(\mathrm{HW}))$ had the mode of $1.8 \pm 0.3 \mu \mathrm{m}$ and the median of $4.5 \pm 0.3 \mu \mathrm{m}(\mathrm{n}=22$ cells) (Figure $1 \mathrm{~F}, \mathrm{H})$. The result suggests that more than $50 \%$ of the territory of a single astrocyte consists of processes with small HW.

Spontaneous $\mathrm{Ca}^{2+}$ activity in astrocytes was recorded at $34^{\circ} \mathrm{C}$ with time-lapse imaging at a speed of 2 frames per second in the presence of $\mathrm{Na}^{+}$channel, mGluR, NMDA, AMPA, GABA $A_{B}$, and P2 receptors' blockers. In agreement with previous reports, conventional region of interest (ROI)-based analysis demonstrated compartmentalization of $\mathrm{Ca}^{2+}$ transients (Figure 2A,B) (Di Castro et al., 2011; Haustein et al., 2014; Inagaki, Fukui, Ito, Yamatodani, \& Wada, 1991; Shigetomi, Kracun, Sofroniew, \& Khakh, 2010). However, this analysis provides very limited spatial information and cannot accurately locate the starting points of $\mathrm{Ca}^{2+}$ events. $\mathrm{Ca}^{2+}$ transients detected in a particular ROI may not start there, but propagate from other, sometimes, very distant parts of the cell (Agarwal et al., 2017; Heller \& Rusakov, 2015; Wu et al., 2014). Therefore, we performed pixel-by-pixel analysis and identified the entire territories of individual $\mathrm{Ca}^{2+}$ events in each frame (see Materials and Methods). The volume formed by spatiotemporally inter-connected pixels belonging to the same $\mathrm{Ca}^{2+}$ transient was defined as a 'whole $\mathrm{Ca}^{2+}$ event'. Indeed, $\mathrm{Ca}^{2+}$ transients detected with ROI-based method represented different parts of whole $\mathrm{Ca}^{2+}$ events reconstructed in $x$ - $y$ - time 3D space (Figure 2C,D and Supporting Information Movie 1). To identify the initiation point of each whole $\mathrm{Ca}^{2+}$ event, we analyzed the frame in which the event was first detected and calculated the centroid of the detected event area (weighted by $\Delta F / F$ amplitude of each pixel, Supporting Information Movie 1). Then each initiation point was assigned to the local HW (Figure 2E). Most $\mathrm{Ca}^{2+}$ events started in thin processes (the mode of the event initiation points was at the local HW of $2.5 \pm 0.1 \mu \mathrm{m}, \mathrm{n}$ $=22$ cells; Figure 2E,F). Notably, the mode of the initiation points coincided with the mode of the local HWs. This opens a possibility that the spontaneous $\mathrm{Ca}^{2+}$ events 
occurred by chance in every part of the astrocyte. If this is the case, the ratio between the probability density of $\mathrm{Ca}^{2+}$ event initiation points at the particular HWs and the probability density of the local HWs $\left(\operatorname{Pr}\left(\mathrm{Ca}^{2+}\right.\right.$ events $\left.) / \operatorname{Pr}(\mathrm{HW})\right)$ should be equal to 1. However, $\mathrm{Ca}^{2+}$ events occurred in the processes with the $\mathrm{HW}>1 \mu \mathrm{m}$ and $<4 \mu \mathrm{m}$ with higher probability than the chance level, and in the processes with the $\mathrm{HW}<1 \mu \mathrm{m}$ and $>$ $4 \mu \mathrm{m}$ with lower probability than the chance level $(n=22 ; F(1,546)=545.8, p<0.0001$; interaction: $F(25,546)=17.18, p<0.0001$; two-way RM ANOVA; Figure 2G,H).

\subsection{SVR of the process determines the probability of $\mathrm{Ca}^{2+}$ event initiation}

The local HW may not accurately describe the SVR of the process in cultured astrocytes. For example, a very flat process may have a large HW and high SVR. To calculate the actual SVR, we assumed that GCaMP2 is evenly distributed in the cytoplasm and the amount of baseline fluorescence detected with CCD reflects the height of the astrocyte in each pixel. After recording the fluorescence with CCD, the same samples were transferred to the confocal microscope and z-stack was obtained. The actual height calculated from z-stack was used to determine the conversion factor of CCD-recorded fluorescence to process height (Figure 3A-D). A heatmap of SVRs was created for each recorded astrocyte (Figure 3E). The distribution of the local SVRs, had the mode of $0.74 \pm 0.04 \mu \mathrm{m}^{-1}$ and the median of $0.72 \pm 0.04 \mu \mathrm{m}^{-1}$ ( $\mathrm{n}=22$ cells, Figure 3F).

Most $\mathrm{Ca}^{2+}$ events started in processes with the SVR $>1 \mu \mathrm{m}^{-1}$ (the mode of event initiation points was at the local SVR of $1.25 \pm 0.07 \mu \mathrm{m}^{-1}, \mathrm{n}=22$ cells; Figure $3 G$ ). Similarly, we calculated the ratio between probability density of $\mathrm{Ca}^{2+}$ event starting at particular SVRs and the probability density of SVRs $\left(\operatorname{Pr}\left(\mathrm{Ca}^{2+}\right.\right.$ events)/Pr(SVR)). $\mathrm{Ca}^{2+}$ events in the processes with the SVR $\geq 1.2 \mu \mathrm{m}^{-1}$ and $<2 \mu \mathrm{m}^{-1}$ occurred with higher probability than the chance level, and in the processes with the SVR $\leq 0.6 \mu \mathrm{m}^{-1}$ and $>2.4 \mu^{-1}$ lower probability than the chance level $(n=22, F(14,294)=17.21, p<$ 0.0001; interaction: $\mathrm{F}(14,294)=17.21, \mathrm{p}<0.0001$; two-way RM ANOVA; Figure 3H).

Our finding suggests that there is a range of the local SVRs in an astrocyte where spontaneous $\mathrm{Ca}^{2+}$ events predominantly initiate. $\mathrm{Ca}^{2+}$ events have less chance to start in very thin or in thick processes. Absence of $\mathrm{Ca}^{2+}$ stores in thin processes can potentially explain the lack of $\mathrm{Ca}^{2+}$ event initiation points there (Patrushev, Gavrilov, 
Turlapov, \& Semyanov, 2013). However, this does not rule out the existence of 'subthreshold' $\mathrm{Ca}^{2+}$ transients, which could not be detected with frame rate or sensitivity of our imaging, in these processes. In the thicker processes, reduced probability of $\mathrm{Ca}^{2+}$ events can be explained by the low SVR of these processes. Low SVR suggests fewer $\mathrm{Ca}^{2+}$ conductances per volume of the cytosol assuming even surface density of these conductances in the astrocyte. Thus, $\mathrm{Ca}^{2+}$ entry through plasma membrane cannot reach the threshold to trigger $\mathrm{Ca}^{2+}$ release from endogenous $\mathrm{Ca}^{2+}$ stores through $\mathrm{IP}_{3} \mathrm{Rs}$. This phenomenon is illustrated with a cylindrical model of astrocyte representing a chunk of the astrocytic process (See Materials and Methods, Figure 4A). In this model $\mathrm{Ca}^{2+}$ ions stochastically entered the process through the plasma membrane $\left(J_{i n}\right.$, Figure $4 \mathrm{~B})$, leaked from the ER $\left(J_{\text {leak }}\right)$ and were released from the ER through $\operatorname{IP}_{3} \operatorname{Rs}\left(J_{I P 3}\right)$. Both $\mathrm{Ca}^{2+}$ and $\mathrm{IP}_{3}$ were required for activation of the $\mathrm{IP}_{3} \mathrm{Rs}$ as described in $(\mathrm{Y}$. X. Li \& Rinzel, 1994). In the presence of $\mathrm{IP}_{3}$, the $\mathrm{IP}_{3} \mathrm{Rs}$ were activated by low $\left[\mathrm{Ca}^{2+}\right]_{i}$ and inactivated by high $\left[\mathrm{Ca}^{2+}\right]_{\mathrm{i}} . \mathrm{Ca}^{2+}$ was pumped from the cytosol to the ER by SERCA (Jpump) or was moved out of the cell by pumps/exchangers in the plasma membrane $\left(J_{\text {out }}\right)$. The initial $\mathrm{IP}_{3}$ concentration changed due to $\mathrm{Ca}^{2+}$-dependent activation of PLC $\delta\left(J_{I P 3}\right)$. J JGCC depended on a single channel $\mathrm{Ca}^{2+}$ conductance, number of channels and $\mathrm{Ca}^{2+}$ driving force. Because the density of $\mathrm{Ca}^{2+}$ channels was set uniformly on the plasma membrane, the processes with a thicker diameter (lower SVR) had fewer channels per volume of the cytosol. This resulted in smaller fluctuations of baseline $\left[\mathrm{Ca}^{2+}\right]_{i}$ which reached the threshold for $\mathrm{IP}_{3} \mathrm{R}$ activation less frequently. Thus, the frequency of the $\mathrm{IP}_{3} \mathrm{R}$-mediated $\mathrm{Ca}^{2+}$ events was higher in the thinner than in the thicker processes (Figure 4C). At some point the process diameter became smaller than the diameter of the ER $(\sim 1 \mu \mathrm{m})$, and such processes could not accommodate the organelle and thus did not maintain $\mathrm{IP}_{3} \mathrm{R}$-mediated $\mathrm{Ca}^{2+}$ events (Figure $4 \mathrm{C}$ ). Our model reproduced the experimental results showing that the $\mathrm{IP}_{3} \mathrm{R}$-mediated $\mathrm{Ca}^{2+}$ events appear more frequently in a certain range of sizes of astrocytic processes. The model suggests that the local SVR and the presence of the ER in the process are sufficient to explain higher frequency of $\mathrm{Ca}^{2+}$ events in distal astrocytic processes without need for any gradients of $\mathrm{Ca}^{2+}$ channels in the plasma membrane. 


\section{3 $\mathrm{Ca}^{2+}$ entry through VGCCs is involved in spontaneous $\mathrm{Ca}^{2+}$ activity in cultured astrocytes}

In our model, $J_{V G C C}$ depended on the $\mathrm{Ca}^{2+}$ driving force which changes at different concentrations of extracellular $\mathrm{Ca}^{2+}\left(\left[\mathrm{Ca}^{2+}\right]_{0}\right)$. Indeed, nominally $\mathrm{Ca}^{2+}$-free solution $\left(\left[\mathrm{Ca}^{2+}\right]_{0}=10 \mu \mathrm{M}\right)$ suppressed $\mathrm{Ca}^{2+}$ events in the processes of all diameters (Figure 4D), while $\left[\mathrm{Ca}^{2+}\right]_{0}$ elevation from $2 \mathrm{mM}$ to $4 \mathrm{mM}$ increased both the peak frequency of $\mathrm{Ca}^{2+}$ events and extended the "active range" of $\mathrm{HWs}$ where $\mathrm{Ca}^{2+}$ events could be triggered (Figure 4E,F). In agreement with the model prediction, removal of extracellular $\mathrm{Ca}^{2+}$ suppressed $\mathrm{Ca}^{2+}$ events in cultured astrocytes (the effect of HW: $F(19,200)=9.457, p<$ 0.0001; the effect of $\left[\mathrm{Ca}^{2+}\right]_{0}$ removal: $F(1,200)=26.26, p<0.0001$; interaction: $\mathrm{F}(19,200)=5.783, \mathrm{p}<0.0001 ; \mathrm{n}=11$; two-way RM ANOVA; Figure 5) and reduced the active range of $\mathrm{HWs}\left(2 \mathrm{mM}\left[\mathrm{Ca}^{2+}\right]_{0}: 8.7 \pm 1.2 \mu \mathrm{m}, 0 \mathrm{mM}\left[\mathrm{Ca}^{2+}\right]_{0}: 4.8 \pm 0.6 \mu \mathrm{m}, \mathrm{n}=11, \mathrm{p}\right.$ $<0.01$, Wilcoxon signed-rank test). However, this phenomenon may also be explained by a depletion of $\mathrm{Ca}^{2+}$ stores in astrocytes as a result of $\mathrm{Ca}^{2+}$ extrusion from astrocytes. Therefore, we gradually increased $\left[\mathrm{Ca}^{2+}\right]_{0}$ from 2 to $4 \mathrm{mM}$ and showed that both the frequency of $\mathrm{Ca}^{2+}$ events (the effect of HW: $F(19,220)=5.662, p<0.0001$; the effect of $\left[\mathrm{Ca}^{2+}\right]_{\mathrm{o}}: \mathrm{F}(2,240)=35.48, \mathrm{p}<0.0001$; interaction: $\mathrm{F}(38,240)=4.825, \mathrm{p}<0.0001 ; \mathrm{n}=7$, two-way RM ANOVA) and the active range of $\mathrm{HWs}\left(2 \mathrm{mM}\left[\mathrm{Ca}^{2+}\right]_{0}: 7.1 \pm 1.0 \mu \mathrm{m}, 3 \mathrm{mM}\right.$ $\left[\mathrm{Ca}^{2+}\right]_{\mathrm{o}}: 8.1 \pm 1.4 \mu \mathrm{m}, 4 \mathrm{mM}\left[\mathrm{Ca}^{2+}\right]_{\mathrm{o}}: 12.1 \pm 1.6 \mu \mathrm{m}, \mathrm{n}=7, \mathrm{p}<0.01, \mathrm{n}=7$, Friedman test;

Figure 6) were significantly increased. This finding suggests that the transmembrane gradient of $\mathrm{Ca}^{2+}$ concentration directly modulates the frequency of spontaneous $\mathrm{Ca}^{2+}$ events in astrocytes.

Besides $\left[\mathrm{Ca}^{2+}\right]_{0}$, another parameter that determines the transmembrane $\mathrm{Ca}^{2+}$ flow is the $\mathrm{Ca}^{2+}$ membrane conductance of astrocytic plasma membrane. When neuronal network activity is high, activity-dependent changes in extracellular $\mathrm{K}^{+}$concentration can depolarize the astrocyte and increase the open probability of VGCCs (Bellot-Saez, Kekesi, Morley, \& Buskila, 2017; Duffy \& MacVicar, 1994). Therefore, we simulated how changes in membrane potential $\left(\mathrm{V}_{\mathrm{m}}\right)$ can affect the frequency of $\mathrm{Ca}^{2+}$ events in the processes of different diameter. The membrane depolarisation from $-80 \mathrm{mV}$ to $-64 \mathrm{mV}$ increased both the peak frequency of $\mathrm{Ca}^{2+}$ events and extended the range of diameters where $\mathrm{Ca}^{2+}$ events were triggered (Figure $7 \mathrm{~A}, \mathrm{~B}$ ). To test this prediction experimentally, we increased $\left[\mathrm{K}^{+}\right]_{\mathrm{o}}$ from $2 \mathrm{mM}$ to $5 \mathrm{mM}$. Such changes of $\left[\mathrm{K}^{+}\right]_{\mathrm{o}}$ occur in physiological 
range (Bellot-Saez et al., 2017). Indeed, we observed an increase in the frequency of $\mathrm{Ca}^{2+}$ events in thin astrocytic processes (the effect of HW: $\mathrm{F}(19,160)=20.67$, $\mathrm{p}<$ 0.0001 ; the effect of $\left[\mathrm{K}^{+}\right]_{0}: \mathrm{F}(1,160)=8.863, \mathrm{p}=0.0034$; interaction: $\mathrm{F}(19,160)=2.568$, $\mathrm{p}=0.0007 ; \mathrm{n}=9$, two-way RM ANOVA; Figure $7 \mathrm{C}-\mathrm{E}$ ) but no significant increase in the active range of HWs ( $p=0.88, n=9$, Wilcoxon signed-rank test). When we repeated the same experiment in the presence of VGCC blockers $(10 \mu \mathrm{M}$ mibefradil and $20 \mu \mathrm{M}$ nimodipine), the increase of $\mathrm{Ca}^{2+}$ events frequency was no longer observed (the effect of HW: $F(19,100)=13.53, p<0.0001$; the effect of $\left[K^{+}\right]_{0}: F(1,100)=0.1347, p=0.7144$; interaction: $F(19,100)=0.651, p=0.8571 ; n=6$, two-way RM ANOVA; Figure 7F). This finding suggests that the frequency of spontaneous $\mathrm{Ca}^{2+}$ event in thin astrocytic processes can be increased by extracellular $\mathrm{K}^{+}$accumulation during local neuronal activity, through activating of VGCCs in the plasma membrane of astrocytes.

\subsection{The role of TRPA1 channels and mitochondria in spontaneous $\mathrm{Ca}^{2+}$ activity}

TRPA1 channels are also suggested to regulate astrocyte resting $\mathrm{Ca}^{2+}$ levels (Shigetomi et al., 2013; Shigetomi, Tong, Kwan, Corey, \& Khakh, 2012). However, we did not observe a significant effect of TRPA1 blocker (20 $\mu \mathrm{M}$ HC 030031) on the frequency $\mathrm{Ca}^{2+}$ events (the effect of HW: $\mathrm{F}(19,57)=5.577, \mathrm{p}<0.0001$; the effect of $\mathrm{HC}$ 030031: $F(1,3)=0.0126, p=0.92$; interaction: $F(19,57)=0.3351, p=0.9947 ; n=4$, two-way RM ANOVA; Supporting Information Figure 1). This finding does not rule out a possibility of $\mathrm{Ca}^{2+}$ entry through TRPA1 channels which plays a role in the nearest submembrane space.

A recent report suggests that mitochondrial permeability transition pore may transiently open and induces microdomain $\mathrm{Ca}^{2+}$ Transients in astrocytic processes (Agarwal et al., 2017). If this is the case, $\mathrm{Ca}^{2+}$ events initiation points should co-localize with mitochondria. To test this hypothesis, we stained the mitochondria with $50 \mathrm{nM}$ MitoTracker Red CMXRos red fluorescent dye and studied their distribution within individual astrocytes (Supporting Information Figure 2A and 2B). If the higher $\mathrm{Ca}^{2+}$ event initiation frequency is contributed mainly by mitochondrial $\mathrm{Ca}^{2+}$ release, we should expect a higher probability of mitochondrial presence $(\operatorname{Pr}($ Mitochondria)) in processes with small HW (Supporting Information Figure 2C). However, Pr(Mitochondria) was significant lower than $\operatorname{Pr}(\mathrm{HW})$ in small processes and larger than $\operatorname{Pr}(\mathrm{HW})$ in thicker 
processes (the effect of HW: $F(19,114)=16.65, p<0.0001 ; \operatorname{Pr}$ (Mitochondria) vs $\operatorname{Pr}(H W): F(1,6)=1.384, p=0.28$; interaction: $F(19,114)=8.422, p<0.0001 ; n=7$, twoway RM ANOVA, post-hoc Bonferroni's multiple comparison; Supporting Information Figure 2C). This finding suggested that even though mitochondria may contribute to astrocytic $\mathrm{Ca}^{2+}$ activity (Agarwal et al., 2017), it does not explain the morphologydependent $\mathrm{Ca}^{2+}$ activity we observed here.

\section{5 $\mathrm{Ca}^{2+}$ events start in thin distal process in astrocytes in hippocampal slices}

These experiments were done with cultured astrocytes. This preparation allows to image $\mathrm{Ca}^{2+}$ dynamics in an entire astrocyte and to measure the HWs/SVRs of the processes. However, astrocytic culture has major drawbacks, since the cultured astrocytes do not develop complex structure characteristic to astrocytes in vivo and may express non-specific receptors and channels (Lange, Bak, Waagepetersen, Schousboe, \& Norenberg, 2012). Therefore, we performed imaging in hippocampal slices from transgenic animals with astrocyte specific expression of GCaMP2 (Figure 8A). Because fine astrocytic processes were beyond optical resolution and their HWs/SVRs cannot be precisely measured, we estimated the volume fraction (VF) of fine astrocytic processes as the ratio between their fluorescence and the fluorescence of the soma (Medvedev et al., 2014; Plata et al., 2018). Multiple fluorescence profiles were plotted across the soma in each direction and the entire astrocyte map of VFs was generated (Figure 8BD). Notably, the distribution of VFs in astrocytes in slices resembled the distribution of HWs/SVRs in cultured astrocytes (the mode: $1.41 \pm 0.31 \%$ and the median $6.07 \pm$ $0.66 \% ; n=8$ cells; Figure $8 E$ ).

We identified the initiation point of each whole $\mathrm{Ca}^{2+}$ event (Figure 9A,B; Supporting Information Movie 2). Each initiation point was linked to the local VF (Figure 9C). In agreement with the results obtained in cultured astrocytes, most of $\mathrm{Ca}^{2+}$ events started in the sites with low local VF (the mode of event initiation points was at the sites with the VF of $9.06 \pm 1.75 \%, n=8$ cells; Figure 9C). In contrast to the cultured astrocytes, the mode of the initiation points did not precisely coincide with the mode of the local VF. This may be because the mode of the local VF corresponded to the finest astrocytic processes, i.e. 'leaflets'. Since the leaflets are devoid of endogenous $\mathrm{Ca}^{2+}$ stores they 
may not initiate the spreading $\mathrm{Ca}^{2+}$ events analyzed here (Gavrilov et al., 2018; Patrushev et al., 2013).

\section{Discussion}

Our findings demonstrate that the initiation points of spontaneous $\mathrm{Ca}^{2+}$ events are predominately located in thin processes within an optimal range of local HWs/SVRs in cultured astrocytes, and within an optimal range of local VFs within astrocytic domain in hippocampal slices. By combining astrocytic $\mathrm{Ca}^{2+}$ imaging with computational simulation, we show that higher SVR of thin astrocytic processes determines higher frequency of spontaneous $\mathrm{Ca}^{2+}$ events. Larger fluctuation of $\left[\mathrm{Ca}^{2+}\right]_{i}$ occur within limited volume of the cytosol due to stochastic $\mathrm{Ca}^{2+}$ entry through the plasma membrane. Some of such fluctuations reach the threshold for the activation of $\mathrm{IP}_{3} \mathrm{Rs}$, which require $\mathrm{Ca}^{2+}$ as a co-agonist along with $\mathrm{IP}_{3}$ (Bezprozvanny, Watras, \& Ehrlich, 1991; Dupont \& Goldbeter, 1993; Shinohara et al., 2011). Subsequent $\mathrm{Ca}^{2+}$ release from the ER amplifies the suprathreshold $\mathrm{Ca}^{2+}$ fluctuations, triggering longer and larger $\mathrm{Ca}^{2+}$ events detectable with full-frame time-lapse imaging. However, such $\mathrm{Ca}^{2+}$ events do not start in astrocytic leaflets that are devoid of $\mathrm{Ca}^{2+}$ stores (Patrushev et al., 2013). This finding do not rule out that fast $\mathrm{Ca}^{2+}$ sparks occur in these compartments near the plasma membrane because of direct $\mathrm{Ca}^{2+}$ entry (Rungta et al., 2016; Shigetomi et al., 2010). Such sparks may not be detectable in our experimental conditions (resolution and speed of imaging) but still could play a role in astrocyte physiology, e.g. trigger a local release of gliotransmitters. A recent computational study has also suggested that local $\mathrm{Ca}^{2+} \quad$ sparks can be amplified through NCX (Brazhe et al., 2018). Moreover $\mathrm{Ca}^{2+}$ sparks in ER/mitochondria-free leaflets can potentially integrate to trigger spreading $\mathrm{Ca}^{2+}$ events in their parent astrocytic branches containing the $\mathrm{Ca}^{2+}$ stores. This scenario is reminiscent of excitatory postsynaptic potentials (EPSPs) integration and triggering of action potentials in neurons. EPSP amplitude depends both on the number of activated receptors and on the cell input resistance (Blomfield, 1974; Pavlov et al., 2014; Song, Savtchenko, \& Semyanov, 2011). Higher input resistance makes EPSPs larger and increases their chance to trigger an action potential. Similarly, higher SVR of the astrocytic process makes the amplitude of $\left[\mathrm{Ca}^{2+}\right]_{\mathrm{i}}$ fluctuations larger and increases their chance to trigger CICR from endogenous $\mathrm{Ca}^{2+}$ stores. This notion is also supported by the existence of a $\left[\mathrm{Ca}^{2+}\right]_{i}$ gradient in astrocytes: $\left[\mathrm{Ca}^{2+}\right]_{i}$ is larger in thin distal processes 
than in thick proximal processes or in soma (Zheng et al., 2015). Thus, astrocytic $\mathrm{Ca}^{2+}$ activity may be directly regulated by changes in the morphology of astrocytic processes which occur both in physiological and pathological conditions (Heller \& Rusakov, 2015). Retraction of astrocytic leaflets and redistribution of glial fibrillary acidic protein (GFAP) has been reported in astrocytes of supraoptic nucleus during the hormonal changes associated with lactation (Salm, Smithson, \& Hatton, 1985). A decreased astrocytic presence in the synaptic microenvironment promotes glutamate spillover in lactating animals (Oliet, Piet, \& Poulain, 2001). In contrast, synaptic long-term potentiation (LTP) is associated with increased density of astrocytic leaflets around potentiated synapse (Bernardinelli, Muller, \& Nikonenko, 2014; Bernardinelli, Randall, et al., 2014; Wenzel, Lammert, Meyer, \& Krug, 1991). Chronic whisker stimulation also increases astrocytic coverage of synapses in the barrel cortex (Genoud et al., 2006).

Striking changes in morphology of astrocytic processes has been observed during aging (Rodriguez et al., 2014). Age-related changes are complex and region-specific: astrocytes become hypertrophic in hippocampus, while lose processes in the entorhinal cortex. Morphological changes are accompanied by corresponding changes in astrocytic $\mathrm{Ca}^{2+}$ signaling (Lalo, Palygin, North, Verkhratsky, \& Pankratov, 2011). Astrocytic atrophy parallels reduced $\mathrm{Ca}^{2+}$ activity in hippocampal astrocytes in the pilocarpine model of epilepsy (Plata et al., 2018). Astrocytic atrophy has been observed in a transgenic mouse model of Alzheimer's disease (3xTg-AD) in hippocampus as well as entorhinal and prefrontal cortices (Rodriguez, Jones, \& Verkhratsky, 2009). The effect of astrocytic atrophy in 3xTg-AD mice reverses when the animals are subjected to physical activity or are kept in an enriched environment (Rodriguez, Terzieva, Olabarria, Lanza, \& Verkhratsky, 2013). All these lines of evidence suggest that astrocytic processes are highly plastic, and the proportion of branches and leaflets can rapidly change. However, in most cases such changes in astrocytic morphology have been considered in the context of the spatial relationship between astrocytic processes and synapses. Our data suggest that morphological reorganization of astrocytes can be directly translated into changes of their $\mathrm{Ca}^{2+}$ activity. Indeed, an increase in complexity of astrocytic processes during juvenile development parallels an increase in spread of subcellular $\mathrm{Ca}^{2+}$ events in mouse hippocampal astrocytes (Nakayama et al., 2016). 
Although our results suggest that a higher SVR alone can explain a higher probability of $\mathrm{Ca}^{2+}$ events in thin processes, they do not rule out potential contribution of subcellular gradients of receptors, channels and transporters. When we varied $\left[\mathrm{Ca}^{2+}\right]_{0}$ we have observed corresponding changes in the $\mathrm{Ca}^{2+}$ events frequency. The increase in $\left[\mathrm{Ca}^{2+}\right]_{0}$ produced the proportional increase of $\mathrm{Ca}^{2+}$ events in thin and thick processes, suggesting a uniform distribution of $\mathrm{Ca}^{2+}$ conductances. In contrast, $\left[\mathrm{K}^{+}\right]_{\mathrm{o}}$ elevation produced VGCC-dependent increase in the frequency of $\mathrm{Ca}^{2+}$ events only in thin astrocytic processes. This is consistent with a higher density of either $\mathrm{K}_{\mathrm{ir}}$ (responsible for the cell depolarization) or VGCC in thin astrocytic processes (Verkhratsky \& Steinhauser, 2000). Notably, $\mathrm{Ca}^{2+}$ dynamics in astrocytes is strongly influenced by temperature (Komin, Moein, Ellisman, \& Skupin, 2015; Schipke et al., 2008). Here we performed the experiments at $34^{\circ} \mathrm{C}$. However, a previous report suggests that $\mathrm{Ca}^{2+}$ events in astrocytes become more frequent and slower at the room temperature (Schipke et al., 2008). This effect is linked to a decreased strength of SERCA (Komin et al., 2015). As a result, SERCA can pump $\mathrm{Ca}^{2+}$ to ER less efficiently and therefore $\mathrm{Ca}^{2+}$ remains longer in the cytosol. Thus, SERCA strength regulates both the frequency of $\mathrm{Ca}^{2+}$ events and their durations.

One of the major drawbacks of experiments performed in cultured astrocytes is that the cells do not develop in a physiological environment. Cultured astrocytes are morphologically very different and can express receptors and channels which are not characteristic to astrocytes in vivo (Lange et al., 2012). However, the use of cultured astrocytes in the current study was justified. We could image $\mathrm{Ca}^{2+}$ activity within the 'domain' of entire astrocyte and could resolve astrocytic processes using light microscopy. Our conclusions are related purely to astrocyte geometry and can further extrapolated to thinner astrocytic processes found in vivo. To confirm this, we performed two-photon imaging experiments in hippocampal slices of transgenic mouse with astrocyte-specific expression of GCaMP2. Fine astrocytic processes could not be resolved with diffraction-limited optical imaging. To circumvent this problem, we analyzed the local VF of astrocytic processes (Medvedev et al., 2014; Plata et al., 2018). This measure reflects both the thickness and the density of local astrocytic processes. Nevertheless, this approach gave very similar result to the cultured astrocytes: most of the astrocyte's domain is occupied by the territory with low VF and 
most of the $\mathrm{Ca}^{2+}$ events are triggered within an optimal range of these VFs. Another potential caveat of $\mathrm{Ca}^{2+}$ imaging in slices was that the initiation points of $\mathrm{Ca}^{2+}$ events may be located outside of the focal plane. This issue can be addressed in the future experiments with emerging technologies such as three-dimensional $\mathrm{Ca}^{2+}$ imaging (Savtchouk, Carriero, \& Volterra, 2018).

\section{References}

Agarwal, A., Wu, P. H., Hughes, E. G., Fukaya, M., Tischfield, M. A., Langseth, A. J., . . . Bergles, D. E. (2017). Transient Opening of the Mitochondrial Permeability Transition Pore Induces Microdomain Calcium Transients in Astrocyte Processes. NEURON, 93(3), 587-605 e587. doi:10.1016/j.neuron.2016.12.034

Agulhon, C., Petravicz, J., McMullen, A. B., Sweger, E. J., Minton, S. K., Taves, S. R., . .. McCarthy, K. D. (2008). What is the role of astrocyte calcium in neurophysiology? NEURON, 59(6), 932-946. doi:10.1016/j.neuron.2008.09.004

Araque, A., Carmignoto, G., Haydon, P. G., Oliet, S. H., Robitaille, R., \& Volterra, A. (2014). Gliotransmitters Travel in Time and Space. NEURON, 81(4), 728-739. doi:10.1016/j.neuron.2014.02.007

Arizono, M., Bannai, H., Nakamura, K., Niwa, F., Enomoto, M., Matsu-Ura, T., . . . Mikoshiba, K. (2012). Receptor-selective diffusion barrier enhances sensitivity of astrocytic processes to metabotropic glutamate receptor stimulation. Sci Signal, 5(218), ra27. doi:10.1126/scisignal.2002498

Asada, A., Ujita, S., Nakayama, R., Oba, S., Ishii, S., Matsuki, N., \& Ikegaya, Y. (2015). Subtle modulation of ongoing calcium dynamics in astrocytic microdomains by sensory inputs. Physiol Rep, 3(10). doi:10.14814/phy2.12454

Bazargani, N., \& Attwell, D. (2016). Astrocyte calcium signaling: the third wave. Nat Neurosci, 19(2), 182-189. doi:10.1038/nn.4201

Bellot-Saez, A., Kekesi, O., Morley, J. W., \& Buskila, Y. (2017). Astrocytic modulation of neuronal excitability through K+ spatial buffering. Neurosci Biobehav Rev, 77, 8797. doi:10.1016/j.neubiorev.2017.03.002

Bernardinelli, Y., Muller, D., \& Nikonenko, I. (2014). Astrocyte-synapse structural plasticity. Neural Plast, 2014, 232105. doi:10.1155/2014/232105

Bernardinelli, Y., Randall, J., Janett, E., Nikonenko, I., Konig, S., Jones, E. V., . . . Muller, D. (2014). Activity-dependent structural plasticity of perisynaptic astrocytic domains promotes excitatory synapse stability. Curr Biol, 24(15), 1679-1688. doi:10.1016/j.cub.2014.06.025 
Bezprozvanny, I., Watras, J., \& Ehrlich, B. E. (1991). Bell-shaped calcium-response curves of Ins $(1,4,5) \mathrm{P} 3-$ and calcium-gated channels from endoplasmic reticulum of cerebellum. Nature, 351(6329), 751-754. doi:10.1038/351751a0

Bindocci, E., Savtchouk, I., Liaudet, N., Becker, D., Carriero, G., \& Volterra, A. (2017). Three-dimensional $\mathrm{Ca}(2+)$ imaging advances understanding of astrocyte biology. Science, 356(6339). doi:10.1126/science.aai8185

Blomfield, S. (1974). Arithmetical operations performed by nerve cells. Brain Res, 69(1), 115-124.

Brazhe, A. R., Verisokin, A. Y., Verveyko, D. V., \& Postnov, D. E. (2018). SodiumCalcium Exchanger Can Account for Regenerative Ca2+ Entry in Thin Astrocyte Processes. Front Cell Neurosci, 12(250). doi:10.3389/fncel.2018.00250

Carmignoto, G., Pasti, L., \& Pozzan, T. (1998). On the role of voltage-dependent calcium channels in calcium signaling of astrocytes in situ. J Neurosci, 18(12), 4637-4645.

De Young, G. W., \& Keizer, J. (1992). A single-pool inositol 1,4,5-trisphosphatereceptor-based model for agonist-stimulated oscillations in $\mathrm{Ca} 2+$ concentration. Proc Natl Acad Sci U S A, 89(20), 9895-9899.

Di Castro, M. A., Chuquet, J., Liaudet, N., Bhaukaurally, K., Santello, M., Bouvier, D., . . . Volterra, A. (2011). Local Ca2+ detection and modulation of synaptic release by astrocytes. Nat Neurosci, 14(10), 1276-1284. doi:10.1038/nn.2929

Duffy, S., \& MacVicar, B. A. (1994). Potassium-dependent calcium influx in acutely isolated hippocampal astrocytes. Neuroscience, 61(1), 51-61.

Dupont, G., \& Goldbeter, A. (1993). One-pool model for Ca2+ oscillations involving $\mathrm{Ca} 2+$ and inositol 1,4,5-trisphosphate as co-agonists for $\mathrm{Ca} 2+$ release. Cell Calcium, 14(4), 311-322.

Fumagalli, M., Brambilla, R., D'Ambrosi, N., Volonte, C., Matteoli, M., Verderio, C., \& Abbracchio, M. P. (2003). Nucleotide-mediated calcium signaling in rat cortical astrocytes: Role of P2X and P2Y receptors. Glia, 43(3), 218-203. doi:10.1002/glia.10248

Gavrilov, N., Golyagina, I., Brazhe, A., Scimemi, A., Turlapov, V., \& Semyanov, A. (2018). Astrocytic Coverage of Dendritic Spines, Dendritic Shafts, and Axonal Boutons in Hippocampal Neuropil. Front Cell Neurosci, 12(248). doi:10.3389/fncel.2018.00248

Genoud, C., Quairiaux, C., Steiner, P., Hirling, H., Welker, E., \& Knott, G. W. (2006). Plasticity of astrocytic coverage and glutamate transporter expression in adult mouse cortex. PLoS Biol, 4(11), e343. doi:10.1371/journal.pbio.0040343

Haustein, M. D., Kracun, S., Lu, X. H., Shih, T., Jackson-Weaver, O., Tong, X., . . . Khakh, B. S. (2014). Conditions and constraints for astrocyte calcium signaling in 
the hippocampal mossy fiber pathway. NEURON, 82(2), 413-429.

doi:10.1016/j.neuron.2014.02.041

Hayashi, M. K., \& Yasui, M. (2015). The transmembrane transporter domain of glutamate transporters is a process tip localizer. Sci Rep, 5, 9032.

doi:10.1038/srep09032

Heller, J. P., \& Rusakov, D. A. (2015). Morphological plasticity of astroglia:

Understanding synaptic microenvironment. Glia, 63(12), 2133-2151.

doi:10.1002/glia.22821

Hodgkin, A. L., \& Huxley, A. F. (1952). A quantitative description of membrane current and its application to conduction and excitation in nerve. J Physiol, 117(4), 500544.

Inagaki, N., Fukui, H., Ito, S., Yamatodani, A., \& Wada, H. (1991). Single type-2 astrocytes show multiple independent sites of $\mathrm{Ca} 2+$ signaling in response to histamine. Proc Natl Acad Sci U S A, 88(10), 4215-4219.

Kirischuk, S., Kirchhoff, F., Matyash, V., Kettenmann, H., \& Verkhratsky, A. (1999). Glutamate-triggered calcium signalling in mouse bergmann glial cells in situ: role of inositol-1,4,5-trisphosphate-mediated intracellular calcium release. Neuroscience, 92(3), 1051-1059.

Komin, N., Moein, M., Ellisman, M. H., \& Skupin, A. (2015). Multiscale Modeling Indicates That Temperature Dependent [Ca2+]i Spiking in Astrocytes Is Quantitatively Consistent with Modulated SERCA Activity. Neural Plasticity, 2015, 15. doi:10.1155/2015/683490

Lalo, U., Palygin, O., North, R. A., Verkhratsky, A., \& Pankratov, Y. (2011). Agedependent remodelling of ionotropic signalling in cortical astroglia. Aging Cell, 10(3), 392-402. doi:10.1111/j.1474-9726.2011.00682.x

Lange, S. C., Bak, L. K., Waagepetersen, H. S., Schousboe, A., \& Norenberg, M. D. (2012). Primary cultures of astrocytes: Their value in understanding astrocytes in health and disease. Neurochem Res, 37(11), 2569-2588. doi:10.1007/s11064012-0868-0

Latour, I., Hamid, J., Beedle, A. M., Zamponi, G. W., \& Macvicar, B. A. (2003). Expression of voltage-gated Ca2+ channel subtypes in cultured astrocytes. Glia, 41(4), 347-353. doi:10.1002/glia.10162

Letellier, M., Park, Y. K., Chater, T. E., Chipman, P. H., Gautam, S. G., Oshima-Takago, T., \& Goda, Y. (2016). Astrocytes regulate heterogeneity of presynaptic strengths in hippocampal networks. Proc Natl Acad Sci U S A, 113(19), E2685-2694. doi:10.1073/pnas.1523717113

Li, B., Chen, S., Zeng, S., Luo, Q., \& Li, P. (2012). Modeling the contributions of Ca2+ flows to spontaneous Ca2+ oscillations and cortical spreading depression- 
triggered Ca2+ waves in astrocyte networks. PLoS ONE, 7(10), e48534. doi:10.1371/journal.pone.0048534

Li, Y. X., \& Rinzel, J. (1994). Equations for InsP3 receptor-mediated [Ca2+]i oscillations derived from a detailed kinetic model: a Hodgkin-Huxley like formalism. $J$ Theor Biol, 166(4), 461-473. doi:10.1006/jtbi.1994.1041

Liddelow, S. A., Guttenplan, K. A., Clarke, L. E., Bennett, F. C., Bohlen, C. J., Schirmer, L., . . Barres, B. A. (2017). Neurotoxic reactive astrocytes are induced by activated microglia. Nature, 541, 481. doi:10.1038/nature21029

Medvedev, N., Popov, V., Henneberger, C., Kraev, I., Rusakov, D. A., \& Stewart, M. G. (2014). Glia selectively approach synapses on thin dendritic spines. Philos Trans R Soc Lond B Biol Sci, 369(1654), 20140047. doi:10.1098/rstb.2014.0047

Nakayama, R., Sasaki, T., Tanaka, K. F., \& Ikegaya, Y. (2016). Subcellular calcium dynamics during juvenile development in mouse hippocampal astrocytes. The European journal of neuroscience, 43(7), 923-932. doi:10.1111/ejn.13188

Nett, W. J., Oloff, S. H., \& McCarthy, K. D. (2002). Hippocampal astrocytes in situ exhibit calcium oscillations that occur independent of neuronal activity. $J$ Neurophysiol, 87(1), 528-537.

Oliet, S. H., Piet, R., \& Poulain, D. A. (2001). Control of glutamate clearance and synaptic efficacy by glial coverage of neurons. Science, 292(5518), 923-926. doi:10.1126/science.1059162

Oschmann, F., Mergenthaler, K., Jungnickel, E., \& Obermayer, K. (2017). Spatial separation of two different pathways accounting for the generation of calcium signals in astrocytes. PLoS Comput Biol, 13(2), e1005377. doi:10.1371/journal.pcbi.1005377

Palygin, O., Lalo, U., Verkhratsky, A., \& Pankratov, Y. (2010). lonotropic NMDA and $\mathrm{P} 2 \mathrm{X} 1 / 5$ receptors mediate synaptically induced $\mathrm{Ca2+}$ signalling in cortical astrocytes. Cell Calcium, 48(4), 225-231. doi:10.1016/j.ceca.2010.09.004

Parpura, V., Grubisic, V., \& Verkhratsky, A. (2011). Ca(2+) sources for the exocytotic release of glutamate from astrocytes. Biochim Biophys Acta, 1813(5), 984-991. doi:10.1016/j.bbamcr.2010.11.006

Patrushev, I., Gavrilov, N., Turlapov, V., \& Semyanov, A. (2013). Subcellular location of astrocytic calcium stores favors extrasynaptic neuron-astrocyte communication. Cell Calcium, 54(5), 343-349. doi:10.1016/j.ceca.2013.08.003

Pavlov, I., Savtchenko, L. P., Song, I., Koo, J., Pimashkin, A., Rusakov, D. A., \& Semyanov, A. (2014). Tonic GABA(A) conductance bidirectionally controls interneuron firing pattern and synchronization in the CA3 hippocampal network. Proceedings of the National Academy of Sciences of the United States of America, 111(1), 504-509. doi:10.1073/pnas.1308388110 
Petzold, G. C., \& Murthy, V. N. (2011). Role of astrocytes in neurovascular coupling. NEURON, 71(5), 782-797. doi:10.1016/j.neuron.2011.08.009

Plata, A., Lebedeva, A., Denisov, P., Nosova, O., Postnikova, T. Y., Pimashkin, A., . . . Semyanov, A. (2018). Astrocytic Atrophy Following Status Epilepticus Parallels Reduced $\mathrm{Ca} 2+$ Activity and Impaired Synaptic Plasticity in the Rat Hippocampus. Frontiers in Molecular Neuroscience, 11(215). doi:10.3389/fnmol.2018.00215

Riera, J., Hatanaka, R., Uchida, T., Ozaki, T., \& Kawashima, R. (2011). Quantifying the uncertainty of spontaneous Ca2+ oscillations in astrocytes: particulars of Alzheimer's disease. Biophys J, 101(3), 554-564. doi:10.1016/j.bpj.2011.06.041

Rodriguez, J. J., Jones, V. C., \& Verkhratsky, A. (2009). Impaired cell proliferation in the subventricular zone in an Alzheimer's disease model. Neuroreport, 20(10), 907912. doi:10.1097/WNR.0b013e32832be77d

Rodriguez, J. J., Terzieva, S., Olabarria, M., Lanza, R. G., \& Verkhratsky, A. (2013). Enriched environment and physical activity reverse astrogliodegeneration in the hippocampus of AD transgenic mice. Cell Death Dis, 4, e678.

doi:10.1038/cddis.2013.194

Rodriguez, J. J., Yeh, C. Y., Terzieva, S., Olabarria, M., Kulijewicz-Nawrot, M., \& Verkhratsky, A. (2014). Complex and region-specific changes in astroglial markers in the aging brain. Neurobiol Aging, 35(1), 15-23.

doi:10.1016/j.neurobiolaging.2013.07.002

Rojas, H., Colina, C., Ramos, M., Benaim, G., Jaffe, E. H., Caputo, C., \& DiPolo, R. (2007). $\mathrm{Na}+$ entry via glutamate transporter activates the reverse $\mathrm{Na}+\mathrm{Ca}+$ exchange and triggers $\mathrm{Ca}(\mathrm{i}) 2+-$ induced $\mathrm{Ca} 2+$ release in rat cerebellar Type-1 astrocytes. J Neurochem, 100(5), 1188-1202. doi:10.1111/j.14714159.2006.04303.x

Rungta, R. L., Bernier, L. P., Dissing-Olesen, L., Groten, C. J., LeDue, J. M., Ko, R., .. . MacVicar, B. A. (2016). Ca(2+) transients in astrocyte fine processes occur via $\mathrm{Ca}(2+)$ influx in the adult mouse hippocampus. Glia, 64(12), 2093-2103. doi:10.1002/glia.23042

Rusakov, D. A., Zheng, K., \& Henneberger, C. (2011). Astrocytes as regulators of synaptic function: a quest for the Ca2+ master key. Neuroscientist, 17(5), 513523. doi:10.1177/1073858410387304

Salm, A. K., Smithson, K. G., \& Hatton, G. I. (1985). Lactation-associated redistribution of the glial fibrillary acidic protein within the supraoptic nucleus. An immunocytochemical study. Cell Tissue Res, 242(1), 9-15.

Savtchouk, I., Carriero, G., \& Volterra, A. (2018). Studying Axon-Astrocyte Functional Interactions by 3D Two-Photon Ca2+ Imaging: A Practical Guide to Experiments and "Big Data" Analysis. Front Cell Neurosci, 12(98).

doi:10.3389/fncel.2018.00098 
Schipke, C. G., Heidemann, A., Skupin, A., Peters, O., Falcke, M., \& Kettenmann, H. (2008). Temperature and nitric oxide control spontaneous calcium transients in astrocytes. Cell Calcium, 43(3), 285-295.

doi:https://doi.org/10.1016/j.ceca.2007.06.002

Shigetomi, E., Jackson-Weaver, O., Huckstepp, R. T., O'Dell, T. J., \& Khakh, B. S. (2013). TRPA1 channels are regulators of astrocyte basal calcium levels and long-term potentiation via constitutive D-serine release. J Neurosci, 33(24), 10143-10153. doi:10.1523/JNEUROSCI.5779-12.2013

Shigetomi, E., Kracun, S., Sofroniew, M. V., \& Khakh, B. S. (2010). A genetically targeted optical sensor to monitor calcium signals in astrocyte processes. Nat Neurosci, 13(6), 759-766. doi:10.1038/nn.2557

Shigetomi, E., Tong, X., Kwan, K. Y., Corey, D. P., \& Khakh, B. S. (2012). TRPA1 channels regulate astrocyte resting calcium and inhibitory synapse efficacy through GAT-3. Nat Neurosci, 15(1), 70-80. doi:10.1038/nn.3000

Shinohara, T., Michikawa, T., Enomoto, M., Goto, J., Iwai, M., Matsu-ura, T., . . . Mikoshiba, K. (2011). Mechanistic basis of bell-shaped dependence of inositol 1,4,5-trisphosphate receptor gating on cytosolic calcium. Proc Natl Acad Sci U S A, 108(37), 15486-15491. doi:10.1073/pnas.1101677108

Song, I., Savtchenko, L., \& Semyanov, A. (2011). Tonic excitation or inhibition is set by GABA(A) conductance in hippocampal interneurons. Nature communications, 2. doi:10.1038/ncomms1377

Sun, M. Y., Devaraju, P., Xie, A. X., Holman, I., Samones, E., Murphy, T. R., \& Fiacco, T. A. (2014). Astrocyte calcium microdomains are inhibited by Bafilomycin A1 and cannot be replicated by low-level Schaffer collateral stimulation in situ. Cell Calcium, 55(1), 1-16. doi:10.1016/j.ceca.2013.10.004

Tanaka, M., Shih, P. Y., Gomi, H., Yoshida, T., Nakai, J., Ando, R., . . Itohara, S. (2013). Astrocytic Ca2+ signals are required for the functional integrity of tripartite synapses. Mol Brain, 6, 6. doi:10.1186/1756-6606-6-6

Ullah, G., Jung, P., \& Cornell-Bell, A. H. (2006). Anti-phase calcium oscillations in astrocytes via inositol (1, 4, 5)-trisphosphate regeneration. Cell Calcium, 39(3), 197-208. doi:10.1016/j.ceca.2005.10.009

Verkhratsky, A., Orkand, R. K., \& Kettenmann, H. (1998). Glial calcium: homeostasis and signaling function. Physiol Rev, 78(1), 99-141.

Verkhratsky, A., \& Steinhauser, C. (2000). Ion channels in glial cells. Brain Res Brain Res Rev, 32(2-3), 380-412.

Wang, C. M., Chang, Y. Y., Kuo, J. S., \& Sun, S. H. (2002). Activation of P2X(7) receptors induced $[(3) \mathrm{H}] \mathrm{GABA}$ release from the RBA-2 type-2 astrocyte cell line through a $\mathrm{Cl}(-) / \mathrm{HCO}(3)(-)$-dependent mechanism. Glia, 37(1), 8-18. 
Wang, F., Smith, N. A., Xu, Q., Fujita, T., Baba, A., Matsuda, T., . . Nedergaard, M. (2012). Astrocytes modulate neural network activity by $\mathrm{Ca}(2)(+)$-dependent uptake of extracellular K(+). Sci Signal, 5(218), ra26.

doi:10.1126/scisignal.2002334

Wenzel, J., Lammert, G., Meyer, U., \& Krug, M. (1991). The influence of long-term potentiation on the spatial relationship between astrocyte processes and potentiated synapses in the dentate gyrus neuropil of rat brain. Brain Res, 560(12), 122-131.

Wu, Y.-W., Tang, X., Arizono, M., Bannai, H., Shih, P.-Y., Dembitskaya, Y., ... Semyanov, A. (2014). Spatiotemporal calcium dynamics in single astrocytes and its modulation by neuronal activity. Cell Calcium, 55(2), 119-129. doi:10.1016/j.ceca.2013.12.006

Yaguchi, T., \& Nishizaki, T. (2010). Extracellular high K+ stimulates vesicular glutamate release from astrocytes by activating voltage-dependent calcium channels. J Cell Physiol, 225(2), 512-518. doi:10.1002/jcp.22231

Zeng, S., Li, B., Zeng, S., \& Chen, S. (2009). Simulation of spontaneous Ca2+ oscillations in astrocytes mediated by voltage-gated calcium channels. Biophys $\mathrm{J}$, 97(9), 2429-2437. doi:10.1016/j.bpj.2009.08.030

Zheng, K., Bard, L., Reynolds, J. P., King, C., Jensen, T. P., Gourine, A. V., \& Rusakov, D. A. (2015). Time-Resolved Imaging Reveals Heterogeneous Landscapes of Nanomolar $\mathrm{Ca}(2+)$ in Neurons and Astroglia. NEURON, 88(2), 277-288. doi:10.1016/j.neuron.2015.09.043

Zorec, R., Araque, A., Carmignoto, G., Haydon, P. G., Verkhratsky, A., \& Parpura, V. (2012). Astroglial excitability and gliotransmission: an appraisal of $\mathrm{Ca} 2+$ as a signalling route. ASN Neuro, 4(2). doi:10.1042/AN20110061 


\section{Table 1. The parameter values used in the model}

The values of parameters for the $\mathrm{Ca}^{2+}$ fluxes through the membrane of astrocytes or through the membrane of the ER were taken from the previous studies (De Young \& Keizer, 1992; B. Li, Chen, Zeng, Luo, \& Li, 2012; Y. X. Li \& Rinzel, 1994; Ullah et al., 2006; Zeng et al., 2009).

Figure 1. Morphological profile of cultured hippocampal astrocytes

(A) A typical astrocyte in culture expressing the $\mathrm{Ca}^{2+}$ sensor GCaMP2. (B) Fluorescent profiles of three astrocytic processes of different sizes ( $p 1, p 2$, and $p 3)$ marked in (A). The sizes of the processes were defined by their half-width (HW). (C and D) Determining the local HW of astrocytic processes with the minimum cross-section. An enlarged image of astrocytic processes from the boxed area in (A). For each pixel within the astrocytic territory, 18 cross-sections were made with a $10^{\circ}$ increment (white dashlines). (D) Left, representative examples of cross-sections defined in (C). Right, the HW of the process for each pixel was defined as the minimum cross-section length. (E) The local HW of the astrocyte is indicated with the color map. Colder color indicates thinner processes. (F) The probability density distribution of $\mathrm{HWs}(\operatorname{Pr}(\mathrm{HW}))$ in the astrocyte in (E). (G) Four examples of the HW color maps. (H) The mean $\operatorname{Pr}(\mathrm{HW})$ of several astrocytes (thin lines - individual cells, $n=22$ cells, thick line mean $\pm S E M$ ). Dashed line indicates the median $(4.5 \pm 0.3 \mu \mathrm{m})$ of the HW distribution.

\section{Figure 2. $\mathrm{Ca}^{2+}$ events predominantly start in thinner processes of astrocytes}

(A) An image of cultured astrocyte expressing GCaMP2. (B) $\mathrm{Ca}^{2+}$ dynamics in the region-of-interests (ROIs) indicated in (A). (C) A representative example of $X$-Y-time heat map of $\mathrm{Ca}^{2+}$ dynamics $(\Delta \mathrm{F} / \mathrm{F})$. Arrows indicate six examples of $\mathrm{Ca}^{2+}$ transients $(\mathrm{E} 1-$ E6) shown in ROI-based traces in (B). The white contour shows the boundaries of the astrocyte. (D) A representative example of $X$-Y-time binary map of detected whole $\mathrm{Ca}^{2+}$ events. Random colors were assigned to individual events to distinguish their boundaries. The same examples of the detected whole $\mathrm{Ca}^{2+}$ events were indicated with arrows. (E) A representative image of initiation points of $\mathrm{Ca}^{2+}$ events. The centroids of the initial frame of $72 \mathrm{Ca}^{2+}$ events were plotted, and the counts were presented as a 
color map. (F) A representative example of the probability density of $\mathrm{Ca}^{2+}$ events initiation at particular HWs $\left(\operatorname{Pr}\left(\mathrm{Ca}^{2+}\right.\right.$ events), blue line) from the astrocyte in (E). Dashed pink line indicates $\operatorname{Pr}(\mathrm{HW})$ as in Figure 1F. (G) The ratio $\operatorname{Pr}\left(\mathrm{Ca}^{2+}\right.$ events $) / \operatorname{Pr}(\mathrm{HW})$ is equal to 1 when the probability of events initiation at particular $\mathrm{HW}$ is determined by the probability of such $\mathrm{HW}$ in the astrocyte (chance level). The ratio $>1$ suggests that $\mathrm{Ca}^{2+}$ events appear in the processes with this HW above chance level and vice versa for the ration $<1$. (H) The summary of the $\operatorname{Pr}\left(\mathrm{Ca}^{2+}\right.$ events $) / \operatorname{Pr}(\mathrm{HW})$ ratio (thin lines - individual cells, $n=22$ cells, thick line - mean \pm SEM). The $\operatorname{Pr}\left(\mathrm{Ca}^{2+}\right.$ events $) / \operatorname{Pr}(\mathrm{HW})$ ratio was significantly higher that the chance level in the thinner processes and significantly lower in the thicker processes and the soma. ${ }^{*} p<0.05$ ANOVA post-hoc Bonferroni's multiple comparisons.

\section{Figure 3. The optimal range of SVRs for $\mathrm{Ca}^{2+}$ events initiation in astrocytic processes}

(A) A maximum projection of a z-stack of the confocal images of a cultured astrocyte expressing GCaMP2. The thickness of the astrocytic processes was approximated by the HW of fluorescence intensity profile (inset). (B) The CCD image of baseline fluorescence of GCaMP2 of the astrocyte shown in (A). (C) A representative example of the height of the astrocyte in (A) and (B) presented with a heat map. (D) The correlation between the height (estimated by confocal imaging) and the fluorescent intensity (acquired by CCD imaging) of the same processes ( $n=23$ processes $/ 3$ cells). (E) The local SVR of the astrocyte presented as the color map. Hotter color indicates processes with higher SVR. (F) The probability density distribution of SVRs ( $\operatorname{Pr}(S V R))$ of astrocytes (thin lines - individual cells, $n=22$ cells, thick line mean \pm SEM). (G) The probability density of $\mathrm{Ca}^{2+}$ events initiation points at particular SVRs $\left(\operatorname{Pr}\left(\mathrm{Ca}^{2+}\right.\right.$ events), blue line, thin lines - individual cells, $n=22$ cells, thick line mean $\pm S E M)$. Dashed pink line indicates $\operatorname{Pr}(\mathrm{SVR})$ as shown in $(\mathrm{F})$. (H) The summary of the $\operatorname{Pr}\left(\mathrm{Ca}^{2+}\right.$ event $) / \operatorname{Pr}(\mathrm{SVR})$ ratio (thin lines-individual cells, $n=22$ cells, thick line mean $\pm S E M$ ). The ratio was significantly higher than the chance level in the processes with SVRs $\geq 1.2 \mu \mathrm{m}^{-1}$ and $<2 \mu \mathrm{m}^{-1}$. ${ }^{*} \mathrm{p}<0.05$ ANOVA post-hoc Bonferroni's multiple comparison. 
Figure 4. The frequency of spontaneous $\mathrm{Ca}^{2+}$ events depends on the diameter of the model astrocytic process and the $\left[\mathrm{Ca}^{2+}\right]_{0}$

(A) A schematic of a single compartment model of an astrocytic process. (B) Stochastic behavior of modeled $\mathrm{Ca}^{2+}$ influx $\left(J_{i n}\right)$. (C) Reducing the diameter of the modeled process increased the frequency of spontaneous $\mathrm{Ca}^{2+}$ events. Top, representative traces of $\mathrm{Ca}^{2+}$ dynamics in the astrocytic processes of three different diameters - D. Bottom, the frequency of spontaneous $\mathrm{Ca}^{2+}$ events as a function of the diameter of the modeled astrocytic process. (D) The frequency of the spontaneous $\mathrm{Ca}^{2+}$ events is modulated by $\left[\mathrm{Ca}^{2+}\right]_{0}$. Top, representative traces of $\mathrm{Ca}^{2+}$ dynamics in the astrocytic processes of two different diameters at different $\left[\mathrm{Ca}^{2+}\right]_{\mathrm{o}}: 0.01 \mu \mathrm{M}, 2 \mathrm{mM}, 3 \mathrm{mM}$, and $4 \mathrm{mM}$. Bottom, the frequency of the spontaneous $\mathrm{Ca}^{2+}$ events as a function of the diameter of the astrocytic process. (E) The dependency of the $\mathrm{Ca}^{2+}$ event frequency on $\left[\mathrm{Ca}^{2+}\right]_{\mathrm{o}}$ in the astrocytic processes of three different diameters. (F) The effect $\left[\mathrm{Ca}^{2+}\right]_{0}$ on the range of astrocytic process diameters where $\mathrm{Ca}^{2+}$ events occurred ('active range'; green-shaded area). Inset illustrates how the 'active range' was determined in (D). 'min': minimum active diameter; 'max': maximum active diameter.

Figure 5. The frequency of astrocytic $\mathrm{Ca}^{2+}$ events decreases upon removal of the $\left[\mathrm{Ca}^{2+}\right]_{0}$

(A) Representative examples of $X-Y$-time heat maps of $\mathrm{Ca}^{2+}$ dynamics $(\Delta \mathrm{F} / \mathrm{F})$ in $2 \mathrm{mM}$ $\left[\mathrm{Ca}^{2+}\right]_{\mathrm{o}}$ (left) and in $0 \mathrm{mM}\left[\mathrm{Ca}^{2+}\right]_{\mathrm{o}}$ (right). The white contour shows the boundaries of the astrocyte. (B) Same examples as in (A) but presented as X-Y-time binary maps of detected whole $\mathrm{Ca}^{2+}$ events. Random colors were assigned to individual events for distinguishing their boundaries. 382 and 6 events were detected during a 400-second recording in $2 \mathrm{mM}\left[\mathrm{Ca}^{2+}\right]_{0}$ and in $0 \mathrm{mM}\left[\mathrm{Ca}^{2+}\right]_{0}$, respectively. (C) Representative images of initiation points of $\mathrm{Ca}^{2+}$ events in $2 \mathrm{mM}\left[\mathrm{Ca}^{2+}\right]_{0}($ top $)$ and $0 \mathrm{mM}\left[\mathrm{Ca}^{2+}\right]_{\mathrm{o}}$ (bottom). The centroids of the initial frame of the 382 and 6 detected $\mathrm{Ca}^{2+}$ events in $2 \mathrm{mM}\left[\mathrm{Ca}^{2+}\right]_{\mathrm{o}}$ and $0 \mathrm{mM}\left[\mathrm{Ca}^{2+}\right]_{\mathrm{o}}$, respectively, were plotted and the counts were presented as a color map. (D) The summary result of the frequency of event initiation at a given $\mathrm{HW}(\mathrm{n}=11$ cells) in $2 \mathrm{mM}\left[\mathrm{Ca}^{2+}\right]_{\circ}$ (black line) and $0 \mathrm{mM}\left[\mathrm{Ca}^{2+}\right]_{\circ}$ (red line). ${ }^{*} \mathrm{p}<0.05$ ANOVA post-hoc Bonferroni's multiple comparisons. 
Figure 6. The frequency of astrocytic $\mathrm{Ca}^{2+}$ events increases with the $\left[\mathrm{Ca}^{2+}\right]_{0}$ elevation

(A) Representative examples of X-Y-time binary maps of detected whole $\mathrm{Ca}^{2+}$ events in $2 \mathrm{mM}, 3 \mathrm{mM}$, and $4 \mathrm{mM}\left[\mathrm{Ca}^{2+}\right]_{\mathrm{o}}$. Random colors were assigned to individual events. 21, 64 , and 127 events were detected in $2 \mathrm{mM}, 3 \mathrm{mM}$, and $4 \mathrm{mM}\left[\mathrm{Ca}^{2+}\right]_{\mathrm{o}}$, respectively, during each 400-second recording. The white contour shows the boundaries of the astrocyte. (B) Representative images of initiation points of $\mathrm{Ca}^{2+}$ events in $2 \mathrm{mM}, 3 \mathrm{mM}$, and $4 \mathrm{mM}\left[\mathrm{Ca}^{2+}\right]_{0}$. The centroids of the initial frame of the 21,64 , and 127 detected $\mathrm{Ca}^{2+}$ events in $2 \mathrm{mM}, 3 \mathrm{mM}$, and $4 \mathrm{mM}\left[\mathrm{Ca}^{2+}\right]_{\mathrm{o}}$, respectively, were plotted and the counts were presented as color maps. (C) The summary result of the frequency of event initiation at a given HW ( $\mathrm{n}=7$ cells) in $2 \mathrm{mM}$ (black line), $3 \mathrm{mM}$ (red line) and $4 \mathrm{mM}$ (blue line) $\left[\mathrm{Ca}^{2+}\right]_{0}$. ${ }^{*} \mathrm{p}<0.05$ ANOVA post-hoc Bonferroni's multiple comparisons.

\section{Figure 7. VGCC-dependent increase in the frequency of $\mathrm{Ca}^{2+}$ events caused by elevated $\left[\mathrm{K}^{+}\right]_{\mathrm{o}}$}

(A-B) The frequency of spontaneous $\mathrm{Ca}^{2+}$ events can be modulated by resting membrane potentials in the modeled astrocyte. (A) Representative traces of $\mathrm{Ca}^{2+}$ dynamics at three different resting membrane potentials $(-80,-72$, and $-64 \mathrm{mV})$. (B) The frequency of spontaneous $\mathrm{Ca}^{2+}$ events plotted as a function of the diameter of the modeled astrocytic process. (C) Representative examples of X-Y-time binary maps of detected $\mathrm{Ca}^{2+}$ events in the baseline $\left(2 \mathrm{mM}\left[\mathrm{K}^{+}\right]_{\mathrm{o}}\right)$, and at $5 \mathrm{mM}\left[\mathrm{K}^{+}\right]_{\mathrm{o}}$. Random colors were assigned to individual events for distinguishing their boundaries. 120 and 176 events were detected in $2 \mathrm{mM}$ and $5 \mathrm{mM}\left[\mathrm{K}^{+}\right]_{\mathrm{o}}$, respectively, during each 400 -second recordings. The white contour shows the boundaries of the astrocyte. (D) Representative images of initiation points of $\mathrm{Ca}^{2+}$ events in $2 \mathrm{mM}$ and $5 \mathrm{mM}\left[\mathrm{K}^{+}\right]_{\mathrm{o}}$. The centroids of the initial frame of the 120 and 176 detected $\mathrm{Ca}^{2+}$ events in $2 \mathrm{mM}$ and 5 $\mathrm{mM}\left[\mathrm{K}^{+}\right]_{\mathrm{o}}$, respectively, were plotted and the counts were presented as color maps. (E) The summary result of the frequency of event initiation at a given HW ( $\mathrm{n}=9$ cells) in 2 $\mathrm{mM}$ (black line) and $5 \mathrm{mM}$ (red line) $\left[\mathrm{K}^{+}\right]_{0}$. ${ }^{*} \mathrm{p}<0.05$ ANOVA post-hoc Bonferroni's multiple comparisons. (F) The summary result of the frequency of event initiation at a given HW ( $\mathrm{n}=6$ cells) in $2 \mathrm{mM}$ (black line) and $5 \mathrm{mM}$ (red line) $\left[\mathrm{K}^{+}\right]_{\mathrm{o}}$ in the presence of VGCC blockers. 
Figure 8. Morphological profile of astrocytes in hippocampal slices

(A) A typical astrocyte expressing the $\mathrm{Ca}^{2+}$ sensor GCaMP2 in hippocampal slice. Left, the baseline fluorescence of GCAMP2; middle, astrocyte-specific marker, sulforhodamine 101 (SR101); right, merged image of GCaMP2 and SR101. (B) A representative heat map of VF of the astrocyte shown in (A). (C) Three examples of line profiles (3 dashed lines in (B)) of VF aligned to the soma. The VF was used to characterize unresolved astrocytic processes. (D) Representative examples of VF heat map. (E) The mean $\operatorname{Pr}(\mathrm{VF})$ of several astrocytes ( $\mathrm{n}=8$ cells). The dashed line indicates the median (VF: $6.07 \pm 0.66 \%$ ) of VF distribution.

Figure 9. $\mathrm{Ca}^{2+}$ events predominantly start in the parts of astrocytic domain with low astrocytic VF

(A) Left, a representative example of $\mathrm{X}$-Y-time heat map of $\mathrm{Ca}^{2+}$ dynamics $(\Delta \mathrm{F} / \mathrm{F})$ of detected events. The white contour shows the boundaries of the astrocyte. Right, a representative example of $\mathrm{X}-\mathrm{Y}$-time binary map of detected whole $\mathrm{Ca}^{2+}$ events. Random colors were assigned to individual events to distinguish their boundaries. (B) A representative image of event counts of $\mathrm{Ca}^{2+}$ event initiation points (color map) overlapping with the baseline GCaMP2 fluorescence (grey scale). (C) The mean $\mathrm{Ca}^{2+}$ events frequency plotted against the VF of the events initiation points ( $n=8$ cells). (D) Comparison of $\operatorname{Pr}\left(\mathrm{Ca}^{2+}\right.$ events) (blue line) with $\operatorname{Pr}(\mathrm{VF})$ (red dash line re-plotted from Figure $8 \mathrm{E})$ ( $\mathrm{n}=8$ cells). The $\operatorname{Pr}\left(\mathrm{Ca}^{2+}\right.$ events) was significantly higher than $\operatorname{Pr}(\mathrm{FV})$ in thinner processes of VF = $8-18 \%$ (red shaded area) but significantly lower in the finest processes of VF $=0-6 \%$ (grey shaded area). * $\mathrm{p}<0.05$ ANOVA post-hoc Bonferroni's multiple comparisons. 
Table 1

\begin{tabular}{|c|c|c|}
\hline Parameter & Definition & Value \\
\hline$\left[\mathrm{Ca}^{2+}\right]_{\mathrm{cell}}$ & The total cell free $\mathrm{Ca}^{2+}$ concentration in the cell & $2.0 \mu \mathrm{M}$ \\
\hline$c_{1}$ & (ER volume)/(cytosolic volume) & 0.185 \\
\hline$v_{1}$ & Maximal CICR rate & $6.0 \mathrm{~s}^{-1}$ \\
\hline$V_{2}$ & Maximal rate of $\mathrm{Ca}^{2+}$ leak from the $\mathrm{ER}$ & $0.11 \mathrm{~s}^{-1}$ \\
\hline$V_{3}$ & Maximal rate of SERCA uptake & $2.2 \mu \mathrm{M} \mathrm{s}^{-1}$ \\
\hline Jpass & Rate of $\mathrm{Ca}^{2+}$ leak across the plasma membrane & $0.025 \mu \mathrm{M} \mathrm{s}^{-1}$ \\
\hline$V_{6}$ & Maximal rate of activation-dependent $\mathrm{Ca}^{2+}$ influx & $0.2 \mu \mathrm{M} \mathrm{s}^{-1}$ \\
\hline$k_{1}$ & Rate constant of $\mathrm{Ca}^{2+}$ extrusion & $0.5 \mathrm{~s}^{-1}$ \\
\hline$k_{2}$ & Half-saturation constant for $\mathrm{Ca}^{2+}$ entry & $1.0 \mu \mathrm{M}$ \\
\hline$k_{3}$ & SERCA Ca ${ }^{2+}$ affinity & $0.1 \mu \mathrm{M}$ \\
\hline$a_{2}$ & $\mathrm{IP}_{3} \mathrm{R}$ binding rate for $\mathrm{Ca}^{2+}$ inhibition & $0.14 \mu \mathrm{M}^{-1} \mathrm{~s}^{-1}$ \\
\hline$d_{1}$ & Dissociation constant for $\mathrm{IP}_{3}$ & $0.13 \mu \mathrm{M}$ \\
\hline$d_{2}$ & $\mathrm{Ca}^{2+}$ inactivation dissociation constant & $1.049 \mu \mathrm{M}$ \\
\hline$d_{3}$ & Receptor dissociation constant for $\mathrm{IP}_{3}$ & $0.9434 \mu \mathrm{M}$ \\
\hline$d_{5}$ & $\mathrm{Ca}^{2+}$ activation dissociation constant & $0.082 \mu \mathrm{M}$ \\
\hline$\alpha$ & & 0.8 \\
\hline$V_{4}$ & Maximal rate of $\mathrm{IP}_{3}$ production by $\mathrm{PLC} \delta$ & $0.4 \mu \mathrm{M} \mathrm{s}^{-1}$ \\
\hline $1 / \tau_{r}$ & Rate constant for $\mathrm{IP}_{3}$ degradation & $0.14 \mathrm{~s}^{-1}$ \\
\hline$\left[\mathrm{IP}_{3}{ }^{*}\right]$ & Steady state concentration of $\mathrm{IP}_{3}$ & $0.25 \mu \mathrm{M}$ \\
\hline$k_{4}$ & Inhibition constant of PLC $\delta$ activity & $1.1 \mu \mathrm{M}$ \\
\hline \multicolumn{3}{|c|}{ Parameters for VGCCs } \\
\hline$g$ & Conductance density of VGCC & $3.5 \mathrm{pS} \mu \mathrm{m}^{-2}$ \\
\hline$r$ & Radius of an astrocytic process & $0.01-7 \mu \mathrm{m}$ \\
\hline I & Unitary length & $1 \mu \mathrm{m}$ \\
\hline$\pi$ & & 3.14 \\
\hline$R$ & Ideal gas constant & $8.31 \mathrm{~J} \mathrm{~mol}^{-1} \mathrm{~K}^{-1}$ \\
\hline$T$ & Absolute temperature & $293 \mathrm{~K}$ \\
\hline$F$ & Faraday constant & $96485 \mathrm{C} \mathrm{mol}^{-1}$ \\
\hline$z_{K}$ & Valence of $\mathrm{K}^{+}$ & 1 \\
\hline$Z_{\mathrm{Ca}}$ & Valence of $\mathrm{Ca}^{2+}$ & 2 \\
\hline$\varepsilon$ & Modulation factor & $17 \mathrm{mV}$ \\
\hline$\left[\mathrm{Ca}^{2+}\right]_{\mathrm{o}}$ & Extracellular $\mathrm{Ca}^{2+}$ concentration & $10^{-5}-4 \mathrm{mM}$ \\
\hline$\sigma_{m}^{2}$ & Variance of noise & 0.17 \\
\hline
\end{tabular}


bioRxiv preprint doi: https://doi.org/10.1101/410076; this version posted September 6, 2018. The copyright holder for this preprint (which was not certified by peer review) is the author/funder, who has granted bioRxiv a license to display the preprint in perpetuity. It is made available under aCC-BY-NC-ND 4.0 International license.

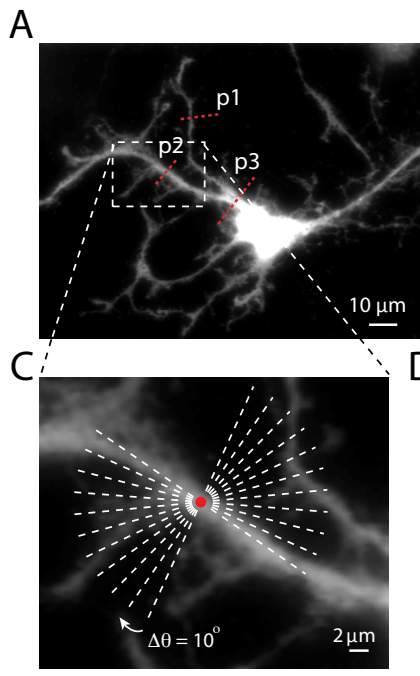

E

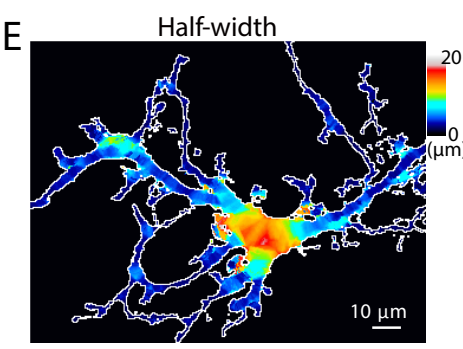

G

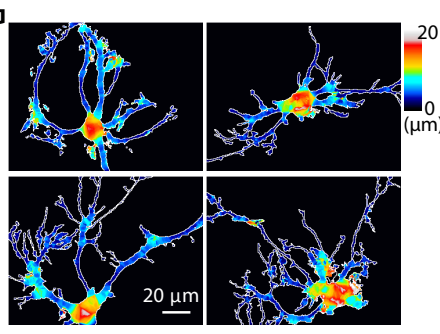

B

$D_{\theta}$
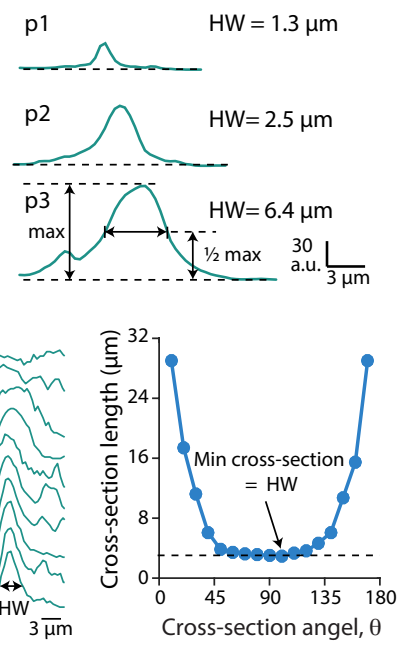

$\mathrm{F}$

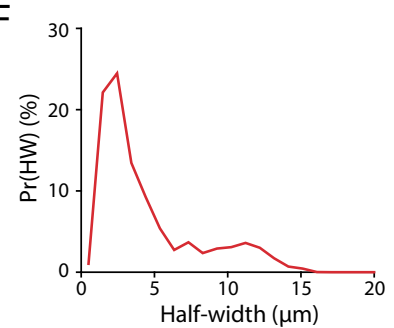

$\mathrm{H}$

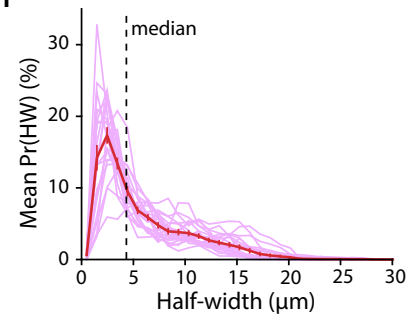

Figure 1 
bioRxiv preprint doi: https://doi.org/10.1101/410076; this version posted September 6, 2018. The copyright holder for this preprint (which was not certified by peer review) is the author/funder, who has granted bioRxiv a license to display the preprint in perpetuity. It is made available under aCC-BY-NC-ND 4.0 International license.
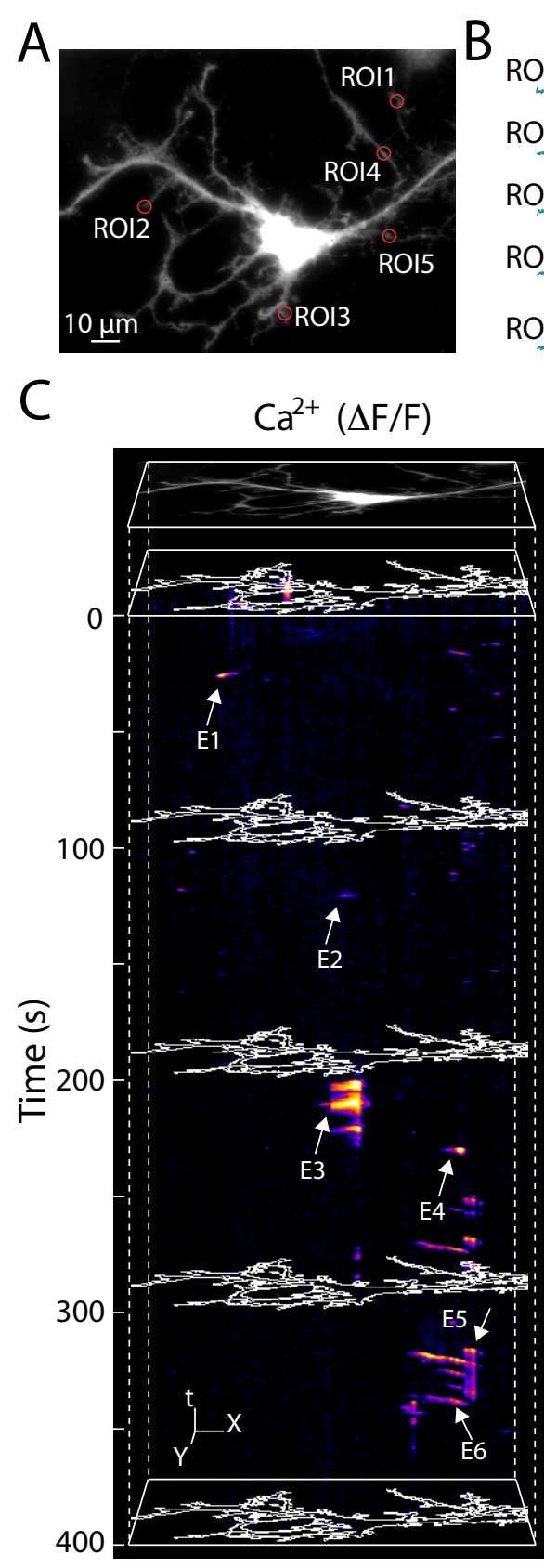

$\Delta \mathrm{F} / \mathrm{F} 0$

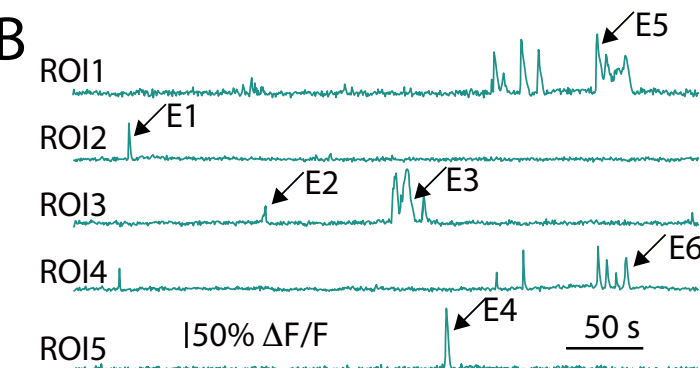

D

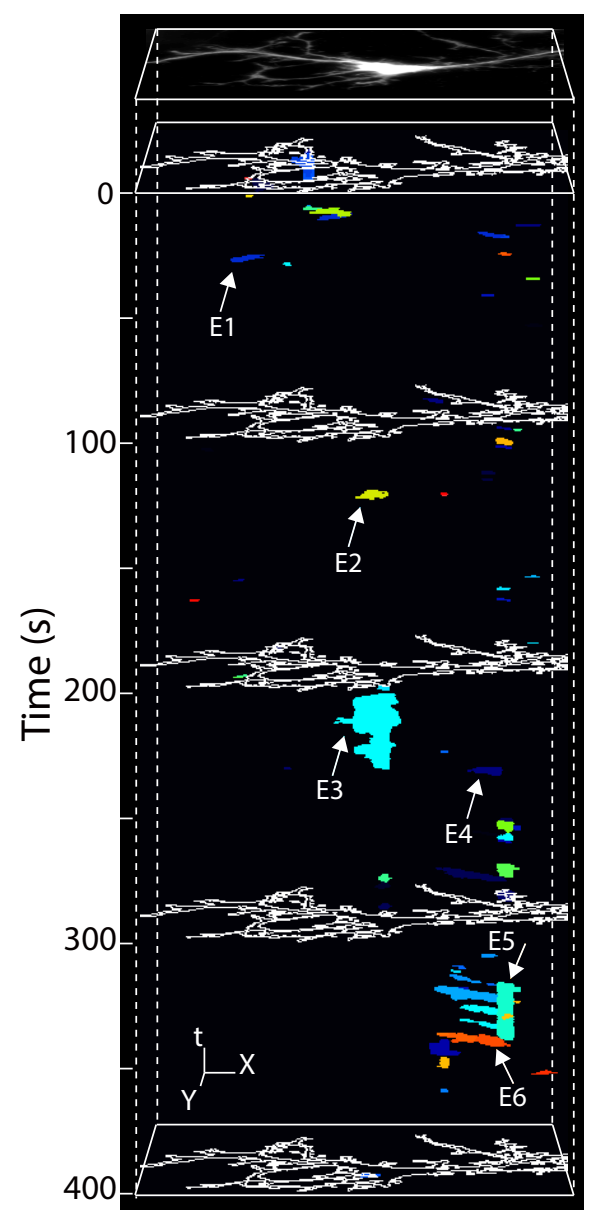

Event ID\# \#1
E $\mathrm{Ca}^{2+}$ event initiation points
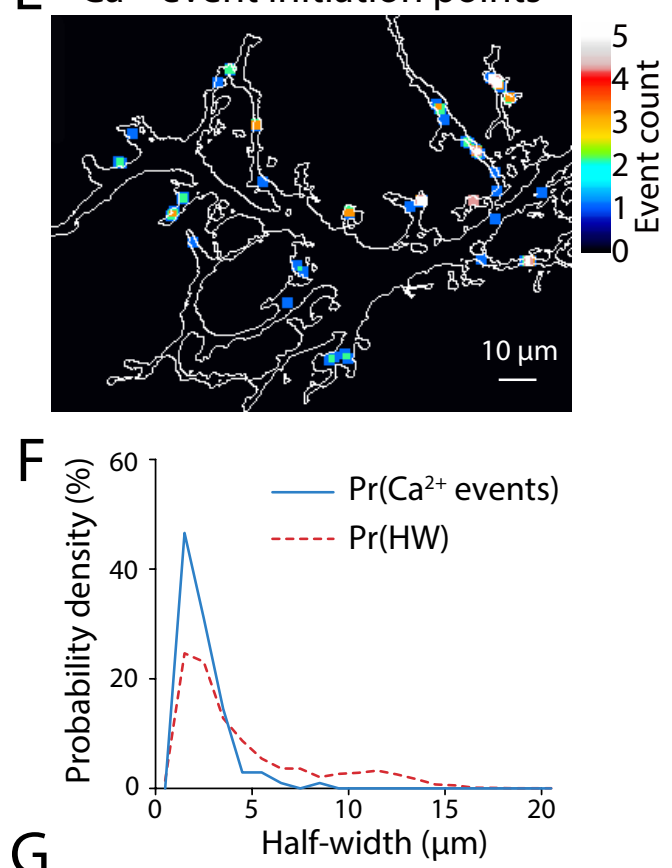

G
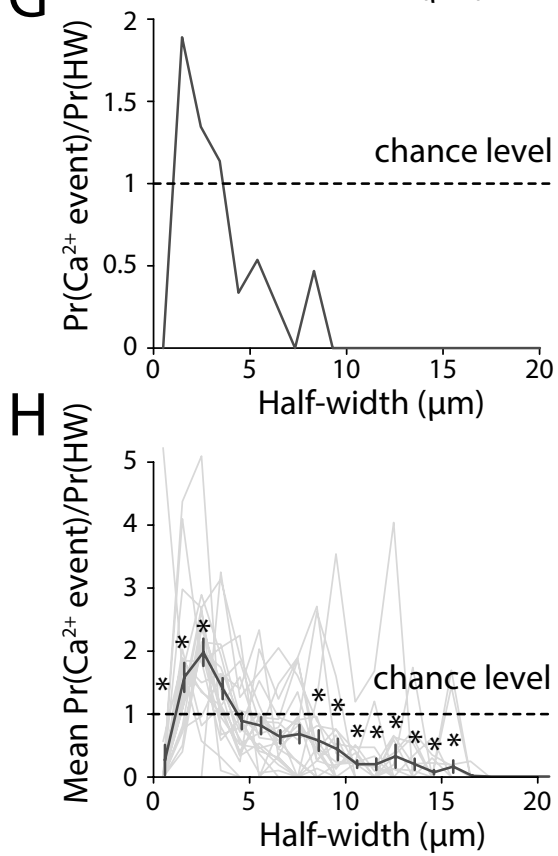

Figure 2 
bioRxiv preprint doi: https://doi.org/10.1101/410076; this version posted September 6, 2018. The copyright holder for this preprint (which was not certified by peer review) is the author/funder, who has granted bioRxiv a license to display the preprint in perpetuity. It is made available under aCC-BY-NC-ND 4.0 International license.
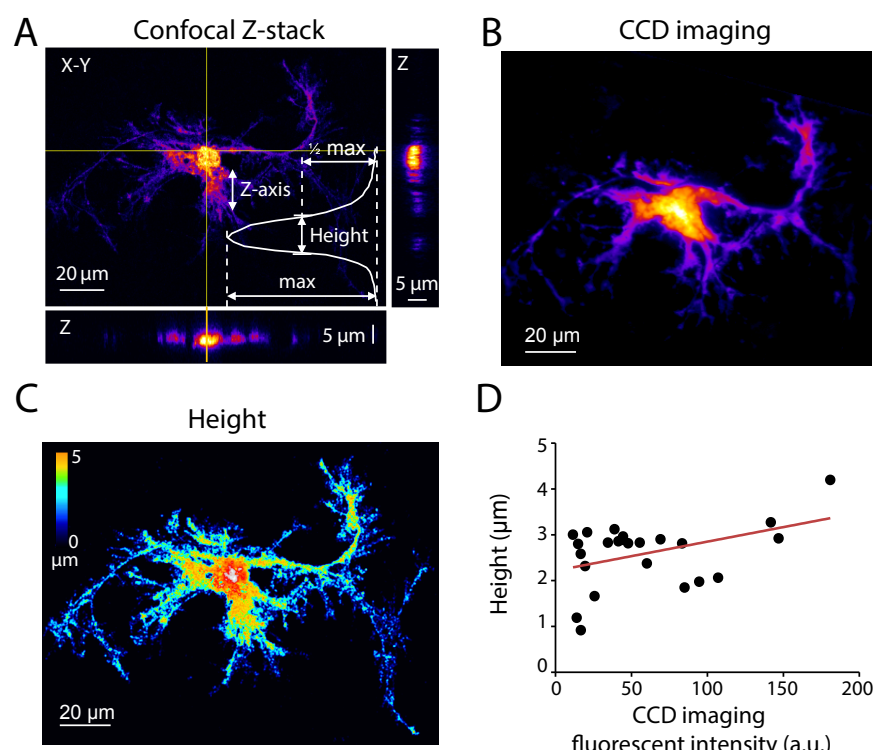

D
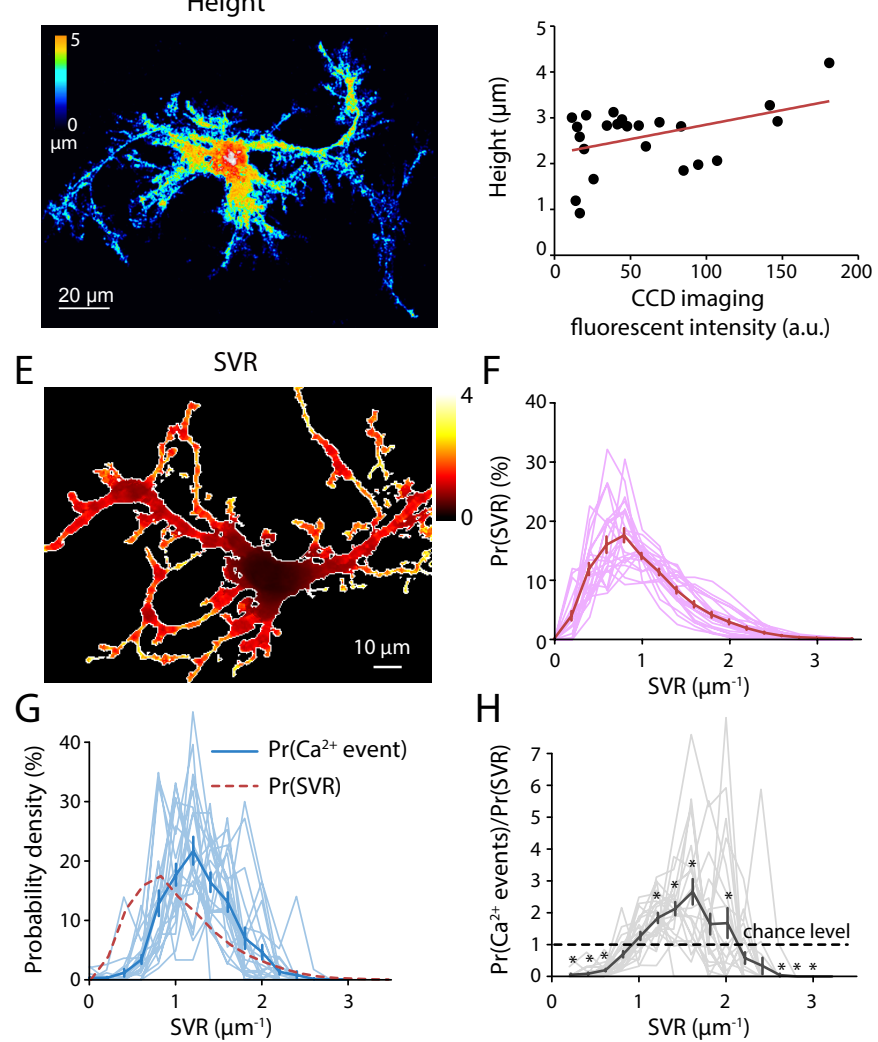

$\mathrm{H}$

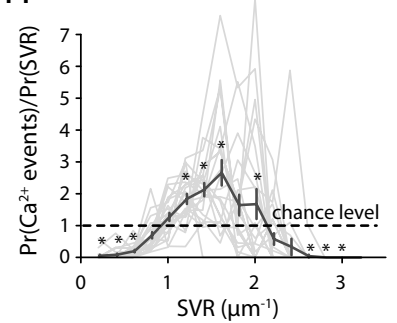

Figure 3 
bioRxiv preprint doi: https://doi.org/10.1101/410076; this version posted September 6, 2018. The copyright holder for this preprint (which was not certified by peer review) is the author/funder, who has granted bioRxiv a license to display the preprint in perpetuity. It is made available under aCC-BY-NC-ND 4.0 International license.

A

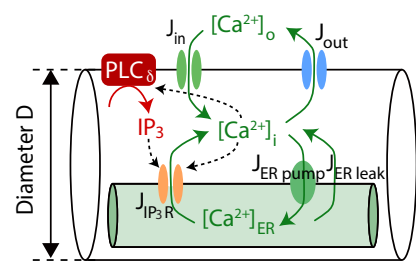

B

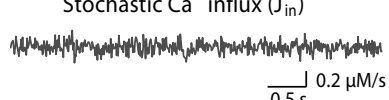

$\mathrm{C} D=8 \mu \mathrm{m}$
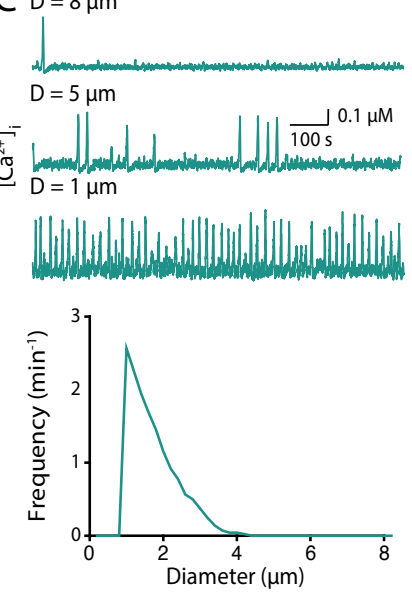

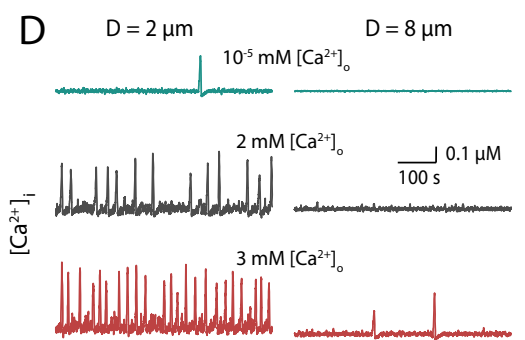

$4 \mathrm{mM}\left[\mathrm{Ca}^{2+}\right]_{0}$
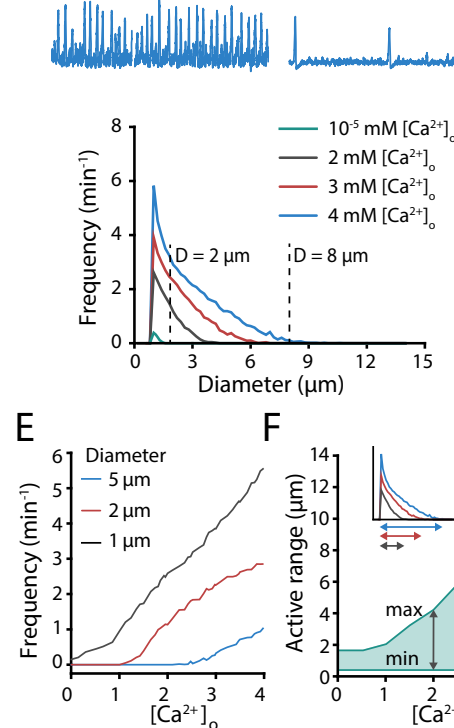

$\mathrm{F}$

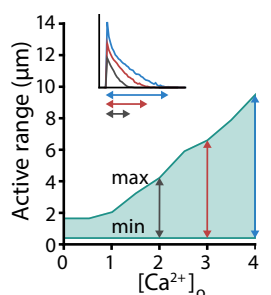


bioRxiv preprint doi: https://doi.org/10.1101/410076; this version posted September 6, 2018. The copyright holder for this preprint (which was not certified by peer review) is the author/funder, who has granted bioRxiv a license to display the preprint in perpetuity. It is made available under aCC-BY-NC-ND 4.0 International license.
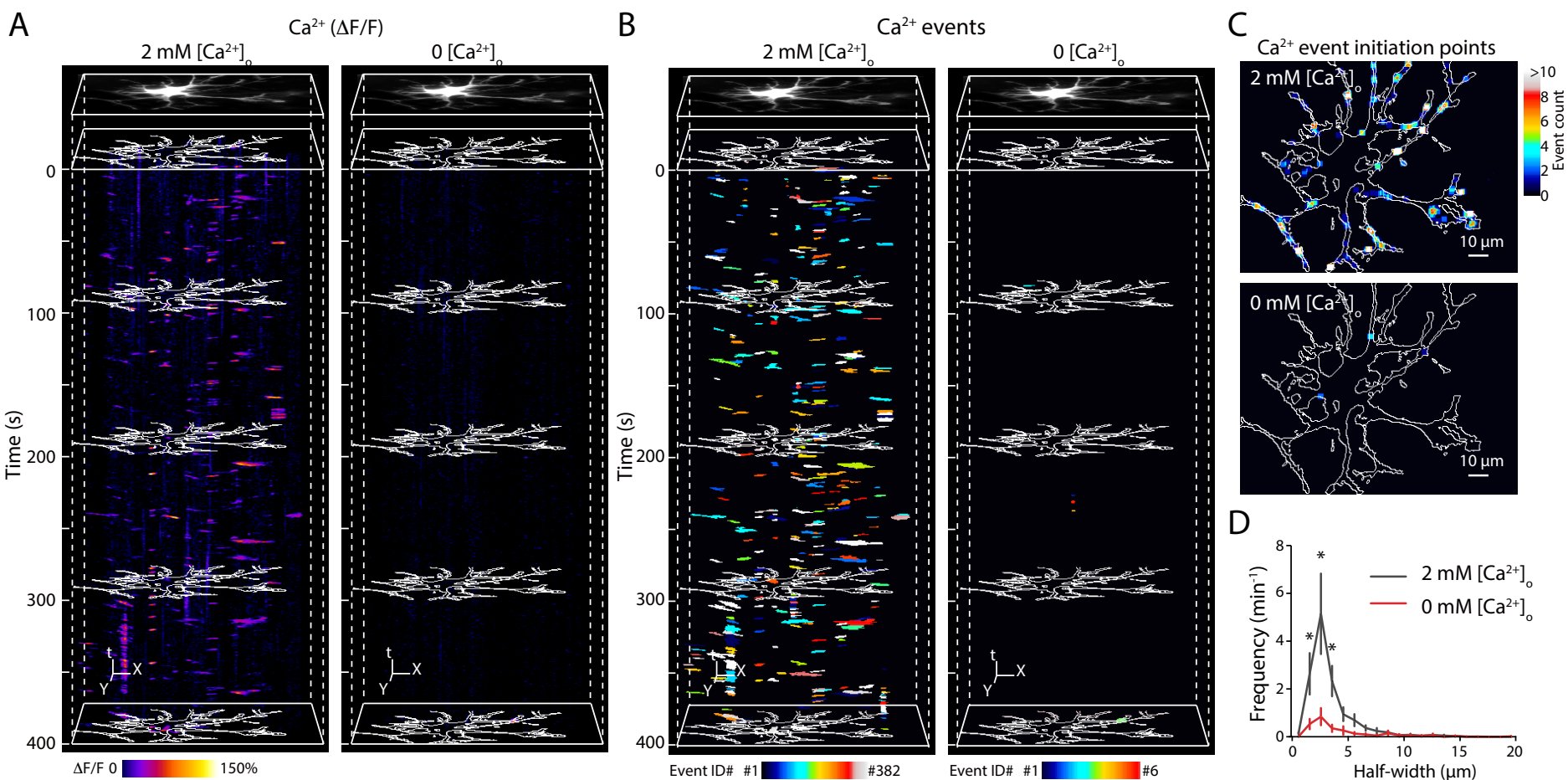

Figure 5 
bioRxiv preprint doi: https://doi.org/10.1101/410076; this version posted September 6, 2018. The copyright holder for this preprint (which was not certified by peer review) is the author/funder, who has granted bioRxiv a license to display the preprint in perpetuity. It is made available under aCC-BY-NC-ND 4.0 International license.
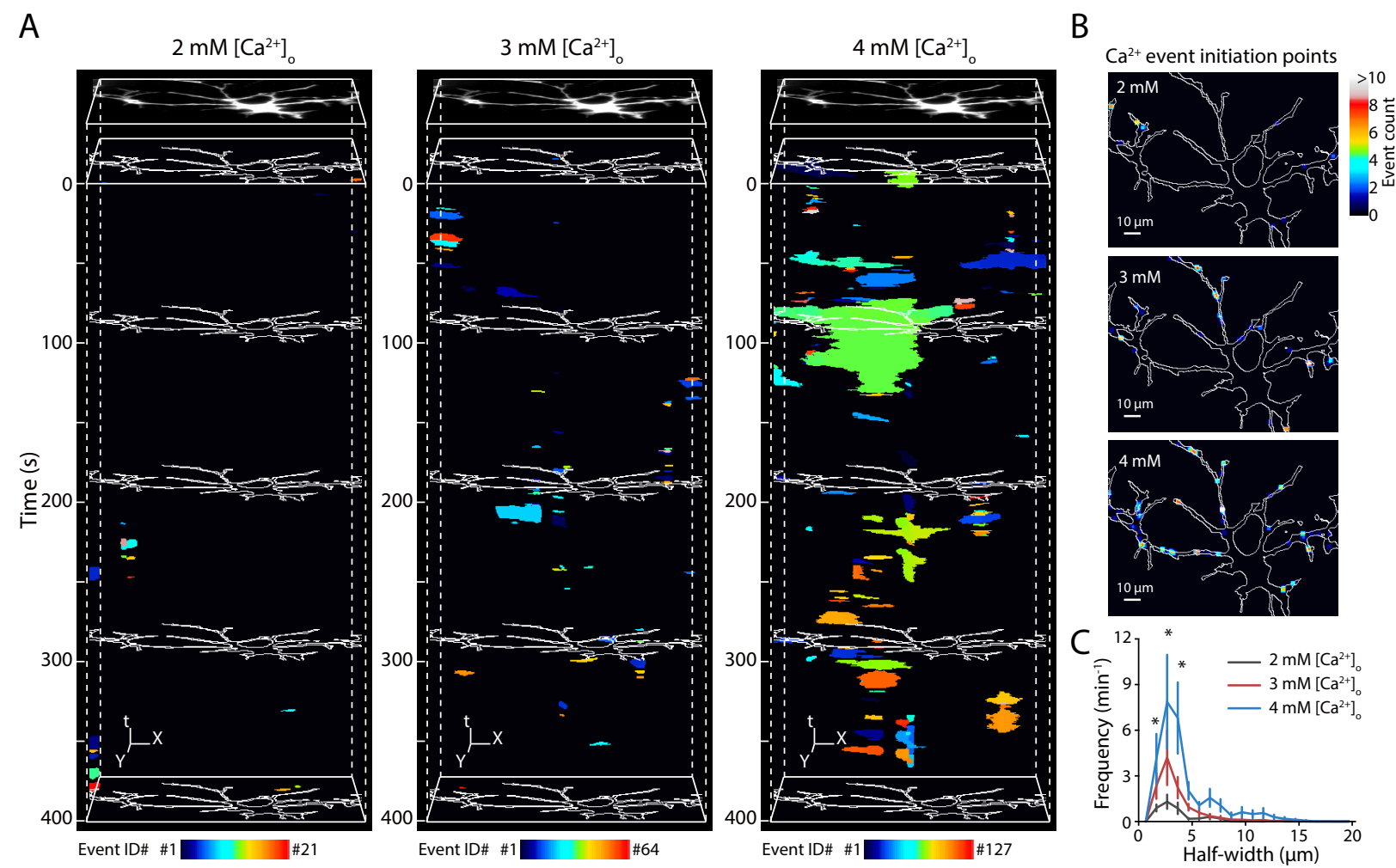

Figure 6 
bioRxiv preprint doi: https://doi.org/10.1101/410076; this version posted September 6, 2018. The copyright holder for this preprint (which was not certified by peer review) is the author/funder, who has granted bioRxiv a license to display the preprint in perpetuity. It is made available under aCC-BY-NC-ND 4.0 International license.
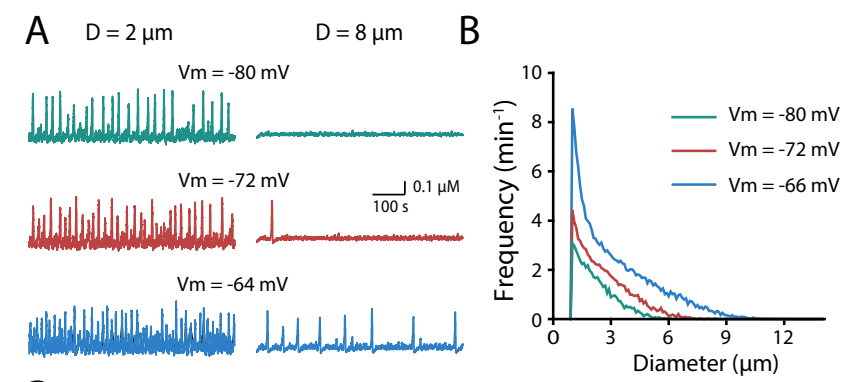

C
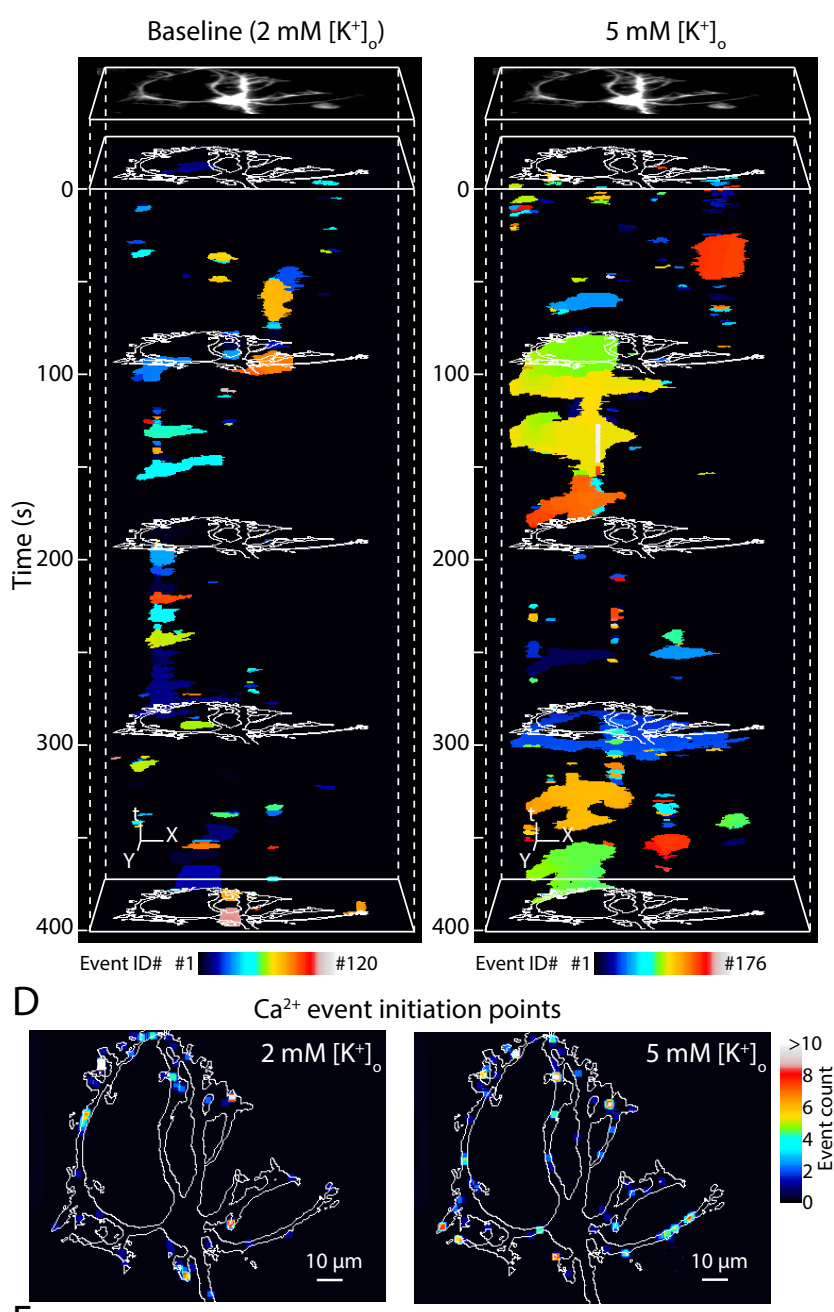

$\mathrm{E}$
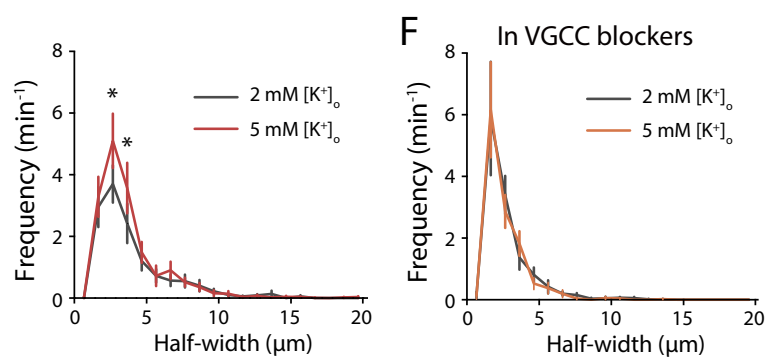

Figure 7 
bioRxiv preprint doi: https://doi.org/10.1101/410076; this version posted September 6, 2018. The copyright holder for this preprint (which was not certified by peer review) is the author/funder, who has granted bioRxiv a license to display the preprint in perpetuity. It is made available under aCC-BY-NC-ND 4.0 International license.

A

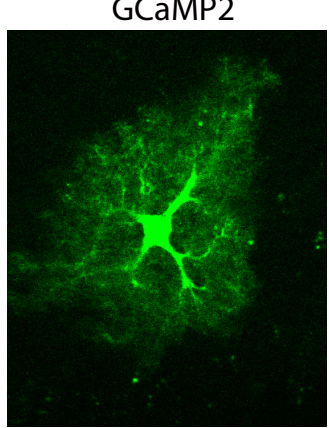

B

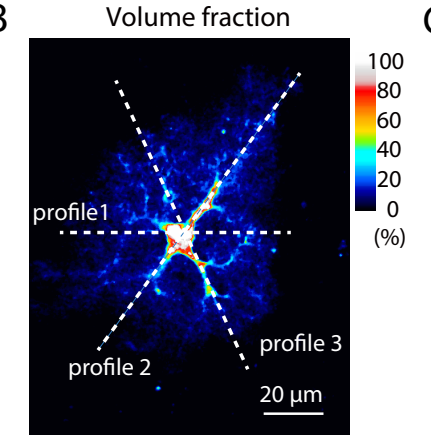

D Volume fraction

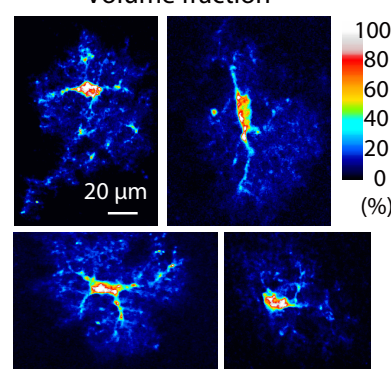

SR101
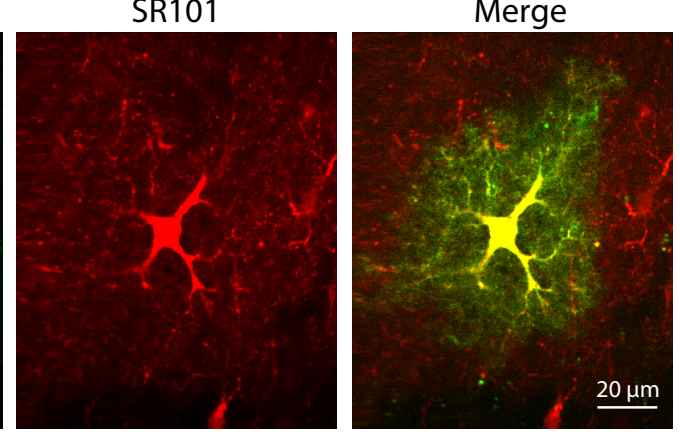

C

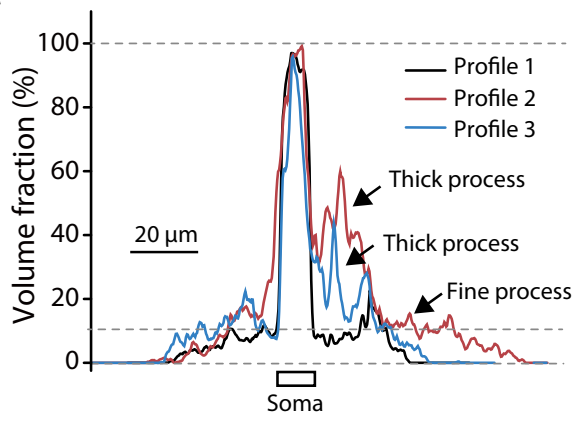

E

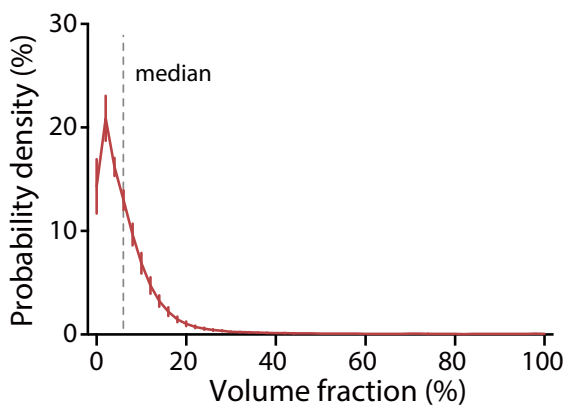


bioRxiv preprint doi: https://doi.org/10.1101/410076; this version posted September 6, 2018. The copyright holder for this preprint (which was not certified by peer review) is the author/funder, who has granted bioRxiv a license to display the preprint in perpetuity. It is made available under aCC-BY-NC-ND 4.0 International license.

A

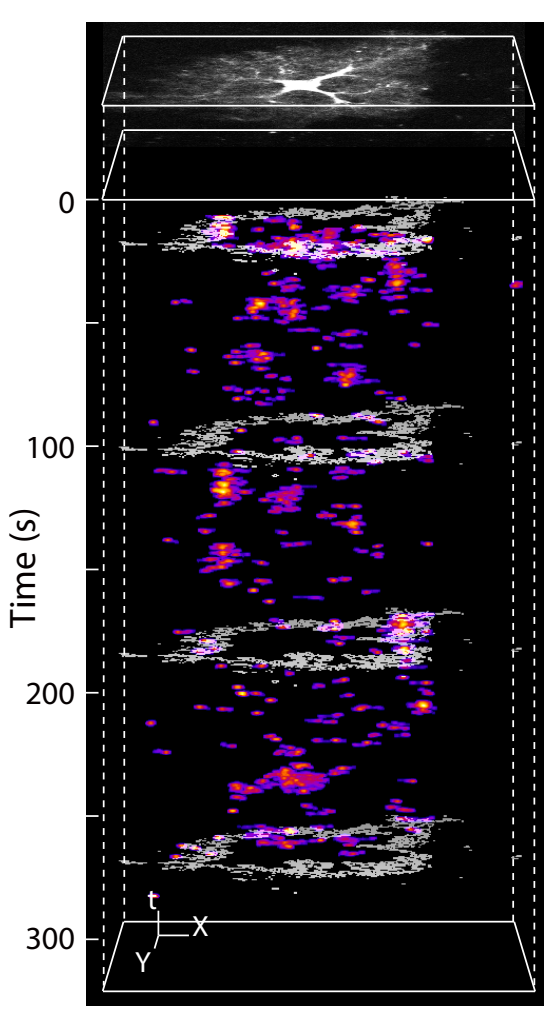

$\Delta \mathrm{F} / \mathrm{F} 0$
$150 \%$
Whole $\mathrm{Ca}^{2+}$ event

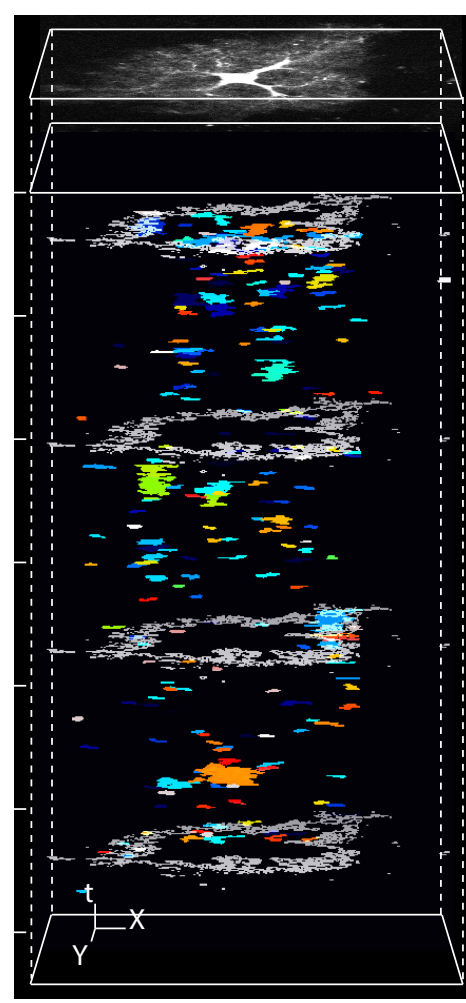

Event ID\# \#1
B

$\mathrm{Ca}^{2+}$ event initiation points

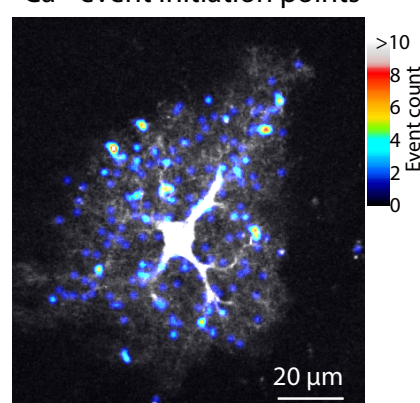

C

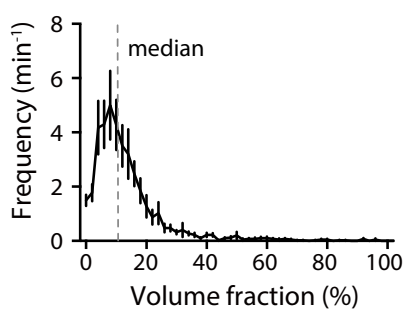

$\mathrm{D}$

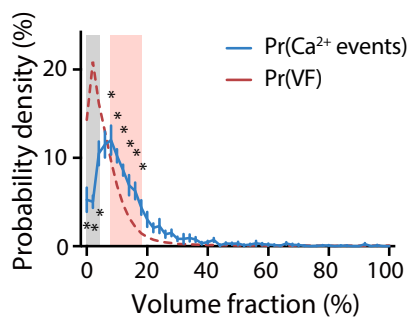

